\title{
Alternative heating systems for northern remote communities: Techno- economic analysis of ground-coupled heat pumps in Kuujjuaq, Nunavik, Canada
}

\author{
Evelyn Gunawan ${ }^{\mathrm{a}, \mathrm{b}}$, Nicolò Giordano ${ }^{\mathrm{b}}$, Páll Jensson ${ }^{\mathrm{a}}$, Juliet Newson ${ }^{\mathrm{a}}$, Jasmin Raymond ${ }^{\mathrm{b}}$ \\ ${ }^{a}$ Reykjavik University, Iceland School of Energy, Menntavegur 1, 101 Reykjavik, Iceland \\ ${ }^{b}$ Institut national de la recherche scientifique (INRS), Centre Eau Terre Environnement, 490 Rue \\ de la Couronne, Québec City, QC G1K 9A9, Canada \\ E-mails: evelyngunawan@alumni.ubc.ca, nicolo.giordano@ete.inrs.ca, pallj@ ru.is, \\ julietn@ru.is, jasmin.raymond@inrs.ca
}

Corresponding author: Evelyn Gunawan

Mailing address: Reykjavik University, Iceland School of Energy, Menntavegur 1, 101

Reykjavik, Iceland

E-mail: evelyngunawan@alumni.ubc.ca 


\section{HIGHLIGHTS}

- Ground source heat pump as a clean and efficient heating alternative

- Applications in remote, subarctic conditions

- Shallow geothermal potential mapped to evaluate project viability

- Economic attractiveness reviewed with 50-years life-cycle cost analysis

- Compression heat pump and solar panels hybrid as cheap and $\mathrm{CO}_{2}$-reducing solution 


\section{ABSTRACT}

Nunavik is a subarctic remote region covering the northern third of Québec, Canada, where low efficiency and environmentally adverse diesel furnaces are currently used to meet residential heating demand. Studies focusing on building heating alternatives in subarctic climate are limited and hence, this work can help with the development of such systems in remote off-grid communities. Shallow geothermal potential was mapped for Kuujjuaq, the largest village in Nunavik. Four ground-coupled heat pump scenarios were analysed for a simulated 5-occupant residential dwelling, with heating needs of $71 \mathrm{MWh} /$ year. Resulting maps show a relatively high ground potential for such cold region, ranging between $5.8 \mathrm{MWh} /$ year and $22.9 \mathrm{MWh} / \mathrm{year}$ per borehole for heat exchanger lengths of $100 \mathrm{~m}$ to $300 \mathrm{~m}$. A 50-year life-cycle cost analysis of such systems reveal that a compression heat pump with electricity derived from solar photovoltaic panels has a net present cost as low as approximately CAD $\$ 179,000$, representing the most economically attractive heating option in Kuujjuaq as compared to the currently subsidized, diesel furnace heating at CAD $\$ 277,000$. This work verifies that shallow geothermal energy through stateof-the-art heat pumps is a financially interesting option in Kuujjuaq. Results can be extended to similar subarctic settings in Canada and worldwide.

Keywords: renewable energy, geothermal, Nunavik, ground-coupled heat pump, G.POT, life cycle cost

\section{INTRODUCTION}

Nunavik, home to 14 Inuit villages with a total of 12,300 inhabitants, is a remote region covering the northern third of Québec province, Canada. These communities are not connected to Québec's electrical grid and hence, are reliant on diesel power plants and furnaces to meet their electricity and building heating demands. In 2018, the price of fuel oil was $\$ 2.03 / 1$, which is subsidized by the local government to $\$ 1.63 / 1$ [1]. Such high cost of fuel is partly associated with the additional cost of fuel transportation from the south to Nunavik. Additionally, diesel is only shipped once a year to these communities. As a result, they are forced to purchase annual supplies of diesel fuel on the spot market, making diesel price volatile in this region [2]. Kuujjuaq, the regional capital of Nunavik, experiences a low annual average temperature of $-5.4^{\circ} \mathrm{C}$ and an annual average of 8,520 heating degree days below $18^{\circ} \mathrm{C}\left(\mathrm{HDD}_{18}\right)$. In Nunavik, houses are typically built to meet the strict regulatory standards for adequate insulation of building envelopes [3]. Despite this, the harsh climate result in high building heating requirement. Furthermore, between 2006 and 2011, the Inuit population in Nunavik increased by $12 \%$ [4]. This combination of high fuel cost, high building heating requirements, increasing demand and adverse environmental impact of fossil fuel combustion calls for the development of new approaches, specifically via renewable energy sources to supply clean, locally-generated and reliable energy in these off-grid communities.

Several alternative energy options have been studied to date. In 2011, hybrid wind-diesel turbine was Hydro-Québec's preferred alternative to reduce fossil fuel consumption in power generation [5]. However, this option was rejected by the communities of Inukjuaq and Whapmagoostui- 
Kuujjuarapik, that preferred hydro-power and connection to the integrated power grid, respectively. Karanasios and Parker [6] reviewed past renewable electricity projects and the available resources for electricity generation in Nunavik. They concluded that despite the available wind resources, wind generation is presently not financially viable in these communities. Yan et al. [7] evaluated alternative technologies such as wood pellets combustion, waste gasification and natural gas through a multi-criteria decision analysis, and ranked the first as the best option for building heating. However, wood pellets need to be imported to the area as there is no local supply, which would mean that energy generation is only partially independent. Additionally, the utilisation of specific shallow geothermal energy technology such as heat pumps was not considered in their analysis. In Nunavik, preliminary evaluations of geothermal resources have been carried out by Comeau et al. [8], Giordano et al. [9] and Miranda et al. [10,11]. Nevertheless, the potential of geothermal energy as a possible solution has not been fully assessed to date. Thus, in this study, ground-coupled heat pump (GCHP) is proposed as a viable alternative to the low efficiency and high greenhouse gas (GHG) emitting diesel furnaces currently used for heating buildings.

GCHP has been successfully installed in cold regions around the world, although its economic viability may vary according to the energy source used to run the GCHP and the cost of that energy. Pike and Whitney [12] reviewed the economic performances of seven GCHPs with vertical borehole heat exchangers (BHEs) in Alaska. The Cold Climate Housing Research Centre [13] in Fairbanks, Alaska found that a GCHP with horizontal BHE performed better-than-expected for the first four years, with coefficient of performance (COP) ranging between 2.82 to 3.69, which plateaued in year 5. In these two studies, the authors noted that the cost effectiveness of GCHP, however, depends on the cost of oil and electricity in the area. The lower the cost of oil, the less cost effective the GCHP system would be compared to the conventional oil furnace heating system. Similarly, Healy and Ugursal [14] concluded that the GCHP with horizontal BHE in Halifax, Canada is more economically viable compared to the oil heating system used in the region.

The main challenges of operating GCHPs in such cold climate relate to the low ground temperature, lower GCHP efficiency, high building heating needs and the fact that the usage of electricity to run the GCHP is not advised by Hydro-Québec as electricity in Nunavik is generated by diesel. Thus, the technical viability of shallow geothermal technology has been tackled in several recent studies. Fontaine et al. [15] proposed a new analytical model for horizontal heat exchangers and applied it to a case study of permafrost stabilization in Kuujjuaq, with heat extraction as a by-product. Heat exchangers at a depth of $2.5 \mathrm{~m}$ can easily keep the ground frozen during summer and at the same time cover the heating needs of the building. Belzile et al. [16] simulated the performance of compression and absorption heat pumps coupled to horizontal ground heat exchangers to partially cover the heating needs of a building in Kangiqsualujjuaq and demonstrated that an absorption heat pump could provide the lowest operating cost with $40 \%$ savings on fuel oil consumption. Giordano and Raymond [17] evaluated the 5-years technical performance of borehole thermal energy storage system for a drinking water facility in Kuujjuaq, showing that a $50 \%$ penetration is technically feasible even in this subarctic climate. Giordano et al. [18] simulated the fluid temperature trend of vertical closed-loop heat exchangers and the ground temperature over 10 years, highlighting that $35 \mathrm{~W} / \mathrm{m}$ can be sustainably retrieved from the 
Kuujjuaq subsurface by a 300-m-deep BHE. A simple financial analysis defined a BHE drilling and installation cost of $\mathrm{CAD} \$ 150 / \mathrm{m}$ as a threshold to guarantee interesting payback times. However, the economical feasibility of such systems through detailed life-cycle cost analysis has never been addressed.

This study aims to quantify the shallow geothermal potential of Kuujjuaq, the capital of Nunavik, by estimating the maximum amount of energy that can be sustainably extracted with a GCHP coupled to vertical BHE installed in shallow subsurface with a relatively cold temperature of slightly above $0^{\circ} \mathrm{C}$, and where this system has never been used in such cold environment. The methodology applied were as follow:

1. Mapping of the shallow geothermal of Kuujjuaq using ground thermal properties data with a geographic information system- (GIS-) based workflow.

2. Simulating the heating load of a typical residential building In Kuujjuaq using the local weather data.

3. Calculating the 50-years life-cycle costs of business-as-usual heating scenario of using diesel furnace and four alternative heating scenarios using GCHP.

This work is expected to serve as a basis for future studies focusing on the applications of GCHP in subarctic conditions, where low ground temperature, unbalanced heating or cooling loads, high cost of BHE drilling and installation, and remoteness of the communities can significantly affect its techno-economic feasibility. However, through this combination of methods, the shallow geothermal resources available, as well as the economic feasibility of the implementation of the GCHP technology can be quantified and analysed for any region globally.

\section{METHODS}

\subsection{Shallow Geothermal Potential Mapping}

The G.POT method developed by Casasso and Sethi [19] (Eq. 1) estimates the shallow geothermal potential or the maximum thermal energy that can be sustainably extracted annually by a closedloop BHE in a homogeneous subsurface. This method can be used for both cooling and heating mode. However, the geothermal potential of Kuujjuaq is calculated only for heating mode as there are very low cooling requirements in the study area.

$$
\bar{Q}_{\mathrm{BHE}}=\frac{0.0701 \cdot\left(T_{0}-T_{\lim }\right) \cdot \lambda \cdot L \cdot t^{\prime}{ }_{\mathrm{c}}}{-0.629 \cdot t^{\prime}{ }^{\prime} \cdot \log \left(u_{\mathrm{s}}{ }_{\mathrm{s}}\right)+\left(0.532 t^{\prime}{ }_{\mathrm{c}}-0.962\right) \cdot \log \left(u^{\prime}{ }_{\mathrm{c}}\right)-0.455 t^{\prime}{ }_{\mathrm{c}}-1.619+4 \pi \lambda \cdot R_{\mathrm{b}}}
$$

The geothermal potential $\bar{Q}_{\mathrm{BHE}}(\mathrm{MWh} /$ year) is dependent on the maximum possible temperature difference between the ground and the fluid $T_{0}-T_{\text {lim }}\left({ }^{\circ} \mathrm{C}\right)$, the ground thermal conductivity $\lambda(\mathrm{W} / \mathrm{mK})$, the borehole length $L(\mathrm{~m})$, the thermal resistance of the borehole $R_{\mathrm{b}}$ 
$(\mathrm{mK} / \mathrm{W})$. The three non-dimensional parameters $u_{\mathrm{s}}^{\prime}, u^{\prime}{ }_{\mathrm{c}}$ and $t^{\prime}{ }_{\mathrm{c}}$ depend on ground heat capacity $(\rho c)$, borehole radius, simulated lifetime of the system, length of the heating season and the load cycle. Tables 1 and 2 summarize the input parameters used to map the geothermal potential. To address the potential problem of thermal imbalance due to long-term heating-only operation of the system, a conservative value for the threshold fluid temperature $T_{\text {lim }}$ of $-5^{\circ} \mathrm{C}$ was assumed.

Table 1 . Thermal conductivity and heat capacity for unconsolidated sediments and bedrock [9,20].

\begin{tabular}{cccc}
\hline & Types & $\begin{array}{c}\lambda \text { saturated } \\
(\mathrm{W} / \mathrm{mK})\end{array}$ & $\begin{array}{c}\rho c \text { saturated } \\
\left(\mathrm{MJ} / \mathrm{m}^{3} \mathrm{~K}\right)\end{array}$ \\
\hline \multirow{3}{*}{ Bedrock Lithology } & Paragneiss & 2.7 & 2.4 \\
& Diorites & 3.0 & 2.4 \\
& Granites & 2.9 & 2.3 \\
& Gabbros & 3.0 & 2.4 \\
& Tonalites & 3.4 & 2.3 \\
\hline \multirow{3}{*}{ Unconsolidated } & Marine & 1.5 & 3.0 \\
Sediments & Alluvial & 1.4 & 3.2 \\
& Glacial Till & 1.6 & 3.0 \\
& Outcrops & 0 & 0 \\
\hline
\end{tabular}

Table 2. Parameters used for mapping the geothermal potential of Kuujjuaq [21].

\begin{tabular}{cccc}
\hline Parameter & Symbol & Values & Unit \\
\hline Threshold fluid temperature & $T_{\text {lim }}$ & -5 & ${ }^{\circ} \mathrm{C}$ \\
Borehole length & $L$ & $100 / 200 / 300$ & $\mathrm{~m}$ \\
Undisturbed ground temperature & $T_{0}$ & $1.0 / 1.75 / 2.75$ & ${ }^{\circ} \mathrm{C}$ \\
Borehole radius & $r_{\mathrm{b}}$ & 0.038 & $\mathrm{~m}$ \\
Simulated lifetime & $t_{\mathrm{s}}$ & 50 & years \\
Length of the heating season & $t_{\mathrm{c}}$ & 270 & days \\
Borehole thermal resistance & $R_{\mathrm{b}}$ & 0.1 & $\mathrm{mK} / \mathrm{W}$ \\
\hline
\end{tabular}

Figure 1 shows the unconsolidated sediments and bedrock geology of Kuujjuaq [22]. Using both QGIS 2.18.21 (QGIS) and Surfer® 9 (Surfer) software [23,24], a depth layer consisting of existing data of depths of unconsolidated sediments obtained from the field study was created and interpolated with the Kriging method using a 300 x $300 \mathrm{~m}$ grid spacing to cover the entire study area (Fig. 2). The unconsolidated sediments are found above the bedrock layer. Where no unconsolidated sediments are found, the bedrock layer shows as an outcrop, which are colored white in Figure 2. 

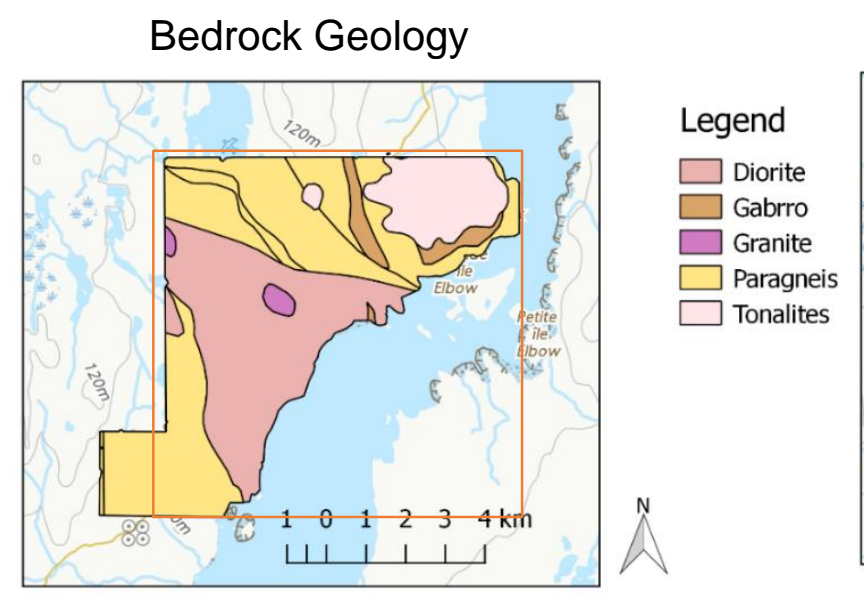

\section{Unconsolidated Sediments}

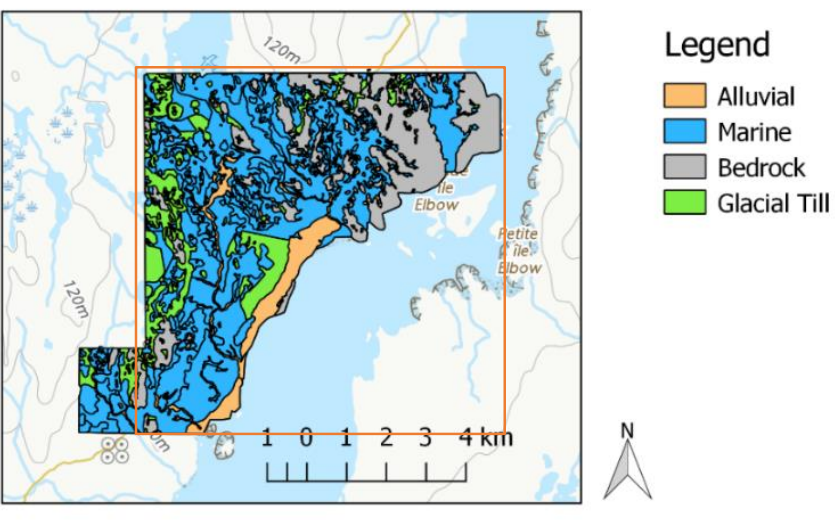

Figure 1. Kuujjuaq bedrock geology (left) and unconsolidated sediments (right). Orange box indicates the extent of the same area in Fig. 2.

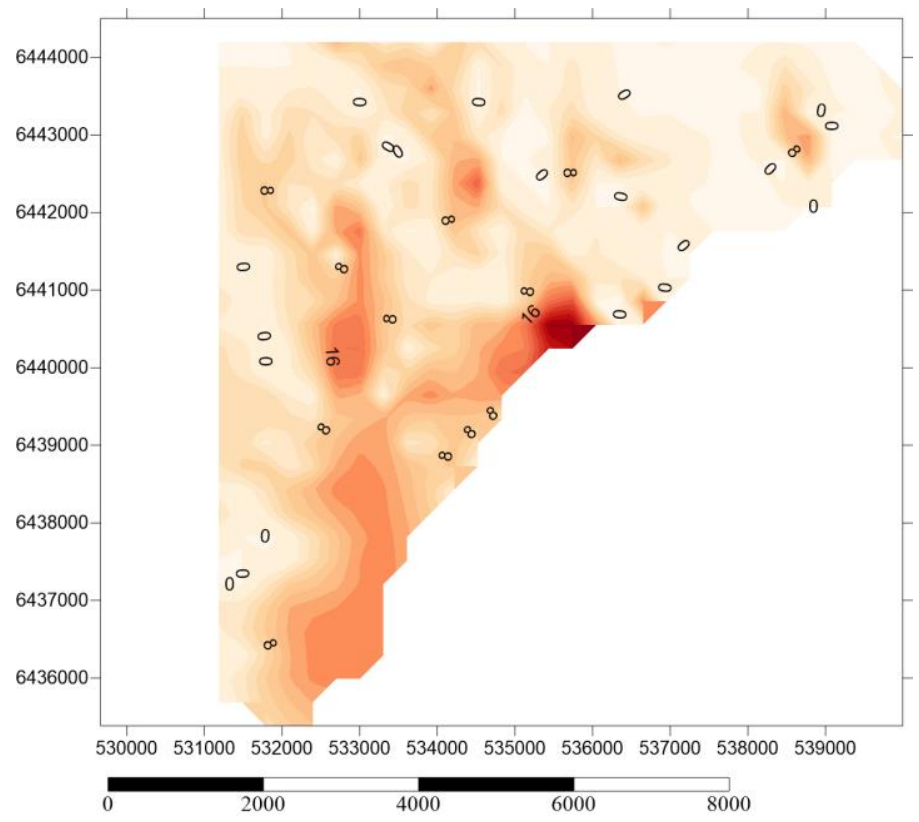

Figure 2. Depth of unconsolidated sediments in Kuujjuaq with bedrock outcrops colored white (labelled $0 \mathrm{~m}$ ) and the deepest quaternary sediments colored dark red $(30 \mathrm{~m})$.

The ground thermal conductivity and heat capacity values for both unconsolidated sediments and bedrock geology were also incorporated to the layer. The weighted thermal conductivity and heat capacity were calculated for $100 \mathrm{~m}, 200 \mathrm{~m}$ and $300 \mathrm{~m}$ BHE lengths scenarios. A sample formula used to calculate the weighted thermal conductivity at $100 \mathrm{~m}$ BHE length is given as follow:

$$
\lambda_{\text {weighted }}=\left(\frac{\text { Depth }}{\text { unconsolidated }} \cdot \lambda_{\text {unconsolidated }}\right)+\left(\frac{100-\text { Dept }_{\text {unconsolidated }}}{100} \cdot \lambda_{\text {bedrock }}\right)
$$

The shallow geothermal potential of Kuujjuaq was calculated for each BHE length scenario by applying Equation 1. 


\subsection{Residential Building Heating Load}

The heating load of a $252 \mathrm{~m}^{2}$, one-floor residential house with 5 occupants was modeled with SIMEB, a software program that provides a simplified interface for the DOE-2 and Energy Plus calculation engines developed to perform building energy simulation, using weather data for Kuujjuaq and known parameters on residential buildings [3,25,26] (Table 3). In this paper, the DOE-2 algorithm was chosen as it is one of the most widely-used building energy modeling programs.

Since current data on building energy usage in Kuujjuaq is limited, hourly load profile data for a typical residential building in Anchorage, Alaska, US, with similar subarctic climate as Kuujjuaq, was initially used to calibrate the input parameters in SIMEB [27]. The building occupancy and usage schedule were adjusted until similar heating load profiles were achieved [28].

Table 3. Main SIMEB input parameters to simulate a typical residential building heating load in Kuujjuaq.

\begin{tabular}{|c|c|c|}
\hline Parameter & Values & Reference \\
\hline \multicolumn{3}{|l|}{ Thermal envelope } \\
\hline Roof insulation & 9 RSI & [28] \\
\hline Wall insulation & $5.11 \mathrm{RSI}$ & [28] \\
\hline Fenestration & $\begin{array}{l}\mathrm{U}: 2.16 \mathrm{~W} / \mathrm{m}^{2} \mathrm{~K} \\
\text { SHGC: } 0.5\end{array}$ & [28] \\
\hline Domestic hot water maximum load & $20.7 \mathrm{~W} / \mathrm{m}^{2}$ & {$[48,49]$} \\
\hline \multicolumn{3}{|l|}{ Central HVAC System } \\
\hline Type & $\begin{array}{l}\text { Single zone: single } \\
\text { supply duct system }\end{array}$ & \\
\hline Cooling & None & \\
\hline \multicolumn{3}{|l|}{ Regulation } \\
\hline Minimum temperature & $21.1^{\circ} \mathrm{C}$ & \multirow{2}{*}{ [27] } \\
\hline Maximum temperature & $24.4^{\circ} \mathrm{C}$ & \\
\hline Perimeter heating & Hydronic baseboard & \\
\hline \multicolumn{3}{|l|}{ Occupation } \\
\hline Sensible heat & $64.5 \mathrm{~W} /$ occupant & \multirow{2}{*}{ [27] } \\
\hline Latent heat & 48.1 W/occupant & \\
\hline
\end{tabular}

\subsubsection{Building Heating Scenarios and Efficiencies}


The building heating systems considered in this study are summarized in Figure 3.

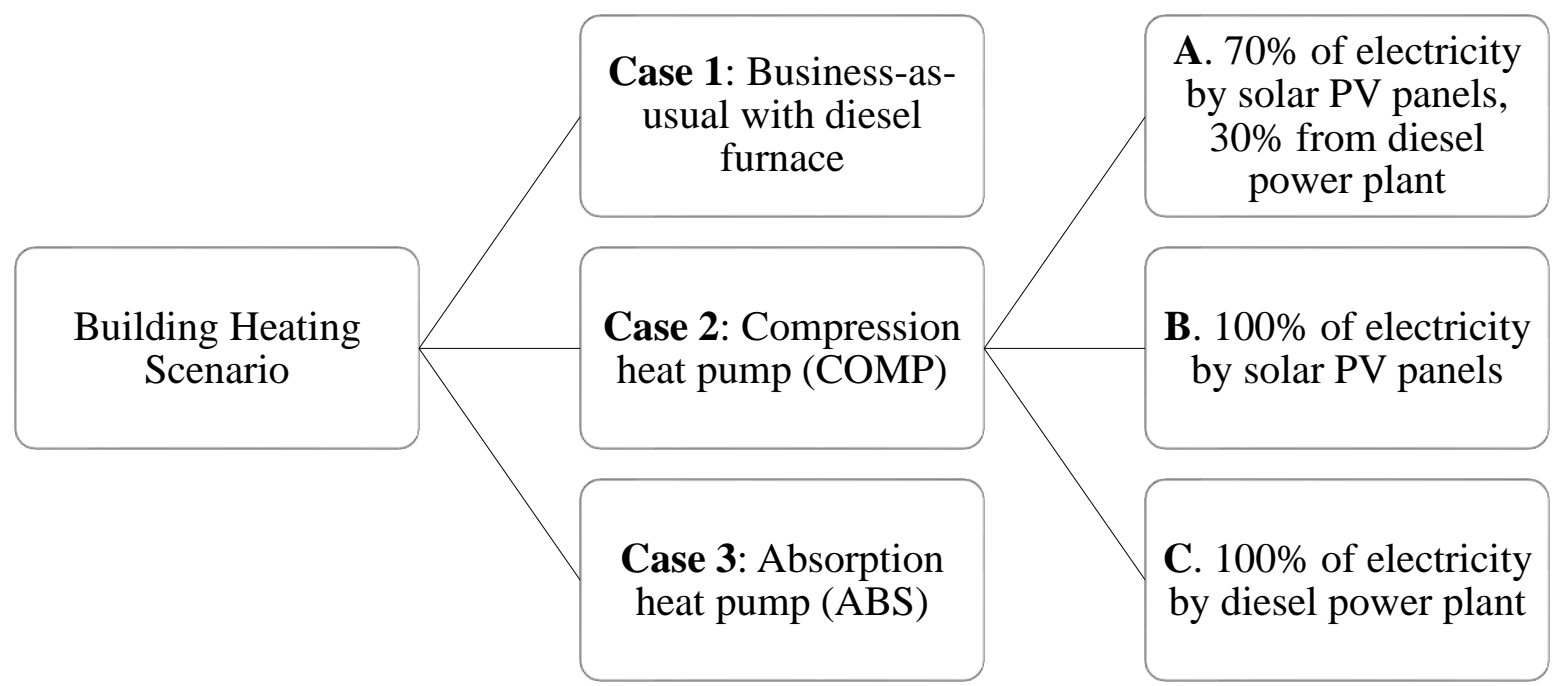

Figure 3. Building heating scenarios.

Both COMP and ABS can provide heating and cooling in building applications. However, COMP runs on electricity to extract geothermal energy, while ABS runs on thermal input, most commonly natural gas. Since diesel is readily available in Kuujuaq, it is assumed the ABS described in Case 3 will be customized to run on diesel. The efficiencies of COMP and ABS are measured in coefficient of performance (COP) and gas utilization efficiency (GUE), respectively, and depend on the entering water temperature (EWT), which is defined as the temperature of fluid entering the heat pump. In turn, the EWT depends on both the BHE configuration and $T_{0}$. In this paper, the EWT was assumed to be equal to $T_{\lim }$ at $-5^{\circ} \mathrm{C}$. COP and GUE are the ratio of the heating supplied to the building to the electrical energy or, in the case of ABS, gas consumed by the compressor. For simplicity, the term COP will be used in this paper to refer to the efficiency of both COMP and ABS. The COP ratings of COMP are typically higher than ABS [28]. The COMP selected for this paper has a COP of 3.1, while the ABS has a COP of 1.2 at the selected EWT [31,32]. In comparison, the efficiency of diesel furnace considered in this paper is $78 \%$ or 0.78 .

Electricity produced by the local diesel power plant is not advised to be used for building heating in Kuujjuaq since it is generated from a diesel power plant at an efficiency of $33.2 \%$, which would lead to much higher subsidies and insufficient nominal capacity of the power plant to cover winter peak demand [32]. Therefore, Cases 2A and 2B consider the generation of electricity from solar photovoltaic (PV) panels.

Sizing a GCHP to provide all the heating required by a house is not normally recommended. The occasional peak heating load during severe weather conditions are usually met by a secondary heating system. Hence, for both Cases 2 and 3, GCHP is sized to meet $50 \%$ of the peak load. The remaining load is assumed to be covered with a diesel furnace.

\subsubsection{Building Energy Consumption}


Based on the simulated total annual building heating load in Kuujjuaq (Table 6), the energy consumptions for each heating scenario and for different heating equipment were calculated according to their efficiencies (or COPs) and energy densities [33] as follows:

1. $1 \mathrm{kWh}$ electricity $=0.0036 \mathrm{GJ}$

2. 11 diesel oil $=0.0387 \mathrm{GJ}$

\subsubsection{BHE Drilling Length}

Based on the average geothermal potential in Kuujjuaq $\left(\bar{Q}_{\mathrm{BHE}}\right)$, the thermal energy available per meter drilled ( $E_{\mathrm{g}}$ available) were calculated for Cases 2 and 3 based on three BHE lengths $(L)$ considered in the G.POT calculation.

$$
E_{\mathrm{g} \text { available }}=\frac{\bar{Q}_{\mathrm{BHE}}}{L}
$$

Based on the total ground load $\left(E_{\mathrm{g}}\right)$, which is the ground thermal energy required to meet the building load with the GCHP system, the total drilling length necessary $\left(L_{\text {drill }}\right)$ can be calculated as follow:

$$
L_{\text {drill }}=\frac{E_{\mathrm{g}}}{E_{\mathrm{g} \text { available }}}
$$

\subsubsection{Solar Panels Quantity}

The number of solar panels required $\left(N_{\mathrm{s}}\right)$ in Scenarios 2A and 2B were calculated by dividing the electricity demand to be met by the solar panels $\left(E_{\mathrm{s}}\right)$ by the energy generated from each panel $\left(E_{\mathrm{S}}\right.$ available). $E_{\mathrm{S}}$ available was calculated by multiplying the solar panel rating, which was assumed to be $0.3 \mathrm{~kW}$ with $1,033 \mathrm{kWh} / \mathrm{kW} /$ year, the solar PV potential in Kuujjuaq [34].

$$
N_{\mathrm{s}}=\frac{E_{\mathrm{S}}}{E_{\mathrm{S} \text { available }}}
$$

\subsection{Life-Cycle Cost Analysis}

\subsubsection{Costs of Heating System}

All costs in this study are in Canadian dollars (CAD), unless otherwise specified. For prices involving United States dollars (USD), the conversion rate 1 USD $=1.272$ CAD on November 6, 2018 was considered [35]. A 14.98\% Québec sales tax was applied to all costs. The total cost $\left(C_{\mathrm{t}}\right)$ was divided to capital costs $\left(C_{\mathrm{c}}\right)$, annual costs $\left(C_{\mathrm{a}}\right)$, and periodic costs $\left(C_{\mathrm{p}}\right.$; Eq. 9). Capital costs include the cost of equipment, installation or labor and shipping. Annual costs include the costs of energy (diesel and/or electricity), maintenance and GHG or carbon dioxide $\left(\mathrm{CO}_{2}\right)$ emissions. Periodic costs include cost of equipment replacement at the end of its lifetime, installation and shipping. 


$$
C_{\mathrm{t}}=C_{\mathrm{c}}+C_{\mathrm{a}}+C_{\mathrm{p}}
$$

Price of fuel: Diesel price in Kuujjuaq is $\$ 2.03 / 1$ before and $\$ 1.63 / 1$ after subsidy [1]. Cost of electricity production by diesel power plant in Kuujjuaq is $\$ 0.86 / \mathrm{kWh}[6]$. With subsidy, the base rate for electricity is $40.64 \mathrm{c} / \mathrm{day}$, in addition to $\$ 5.40 /$ month in the summer and $\$ 6.21 /$ month in the winter, while the variable rate is $5.91 \mathrm{c} / \mathrm{kWh}$ for the first $10,950 \mathrm{kWh}$ per annum and $41.05 \mathrm{c} / \mathrm{kWh}$ thereafter [36].

Price and lifetime of equipment: Prices are summarized in Table 4.

Table 4. Price and lifetime of equipment used in the life-cycle cost analysis.

\begin{tabular}{cccc}
\hline Item & Lifetime (years) & Costs $(\$)$ & Comments and Source \\
\hline Oil tank & 25 & 666.92 & {$[37]$} \\
Boiler & 15 & $3,248.30$ & {$[38]$} \\
COMP and ABS & 20 & $9,480.00$ & $\begin{array}{c}\text { Assumed price for 35 kW } \\
\text { models, which can cover the } \\
\text { heating needs of three houses } \\
\text { Cost per meter, includes labor } \\
\text { Drilling }\end{array}$ \\
Solar panel & 50 & 344.94 & $\begin{array}{c}\text { Price includes labor for } \\
\text { installation [40] }\end{array}$ \\
\hline
\end{tabular}

Labor wage and installation time: An average wage for 13 maintenance and technician jobs in Kuujjuaq was $\$ 26.32$ [41]. It takes two working days for boiler installation and one working day for tank installation. Due to the difference in expertise required, the average wage for heat pump installation is assumed to be $\$ 35.00$. Heat pump installation takes two working days.

Maintenance: Maintenance for all heating scenario is assumed to be conducted annually at $\$ 3.87 / \mathrm{m}^{2}$ for diesel furnace system and $\$ 1.81 / \mathrm{m}^{2}$ for both heat pump systems [42]. Since in Cases 2 and 3 diesel furnaces is only used to meet $50 \%$ of the peak heating demand, the maintenance cost for oil furnace in these cases were halved and added to the heat pump maintenance cost.

Shipping: Shipping of oil tank, oil furnace and heat pumps from Québec City is provided by NEAS cargo shipping company at approximately $\$ 1.15 / \mathrm{kg}$, which includes tax and fuel surcharge [43].

Equipment weight: A 275-gallon oil tank weighs $127 \mathrm{~kg}$. The average weight of seven oil furnaces is $255 \mathrm{~kg}$. The weight of COMP is $316.6 \mathrm{~kg}$ [30]. The weight of ABS is $300 \mathrm{~kg}$ [31]. The weight of wooden pallet packaging for each equipment was assumed at $15 \mathrm{~kg}$. The weight of solar panel was assumed at $15 \mathrm{~kg} / \mathrm{m}^{2}$, while a typical size of a solar panel is $1.64 \mathrm{~m}^{2}$.

\subsubsection{Cost of $\mathrm{CO}_{2}$ Emissions}


The $\mathrm{CO}_{2}$ emissions per $\mathrm{MJ}$ of product of six heating oil companies in North America were averaged and multiplied by the annual diesel consumption to determine the annual carbon dioxide emissions for each heating scenario [44].

The $\mathrm{CO}_{2}$ emissions for each scenario was multiplied with $\$ 19.40 /$ t the estimated price of carbon in Québec's carbon market in 2020, to obtain the cost of $\mathrm{CO}_{2}$ emissions associated with each heating option [45].

\subsubsection{Net Present Cost and Sensitivity Analysis}

A net present cost (NPC) approach was chosen to compare the 50-years life-cycle costs (LCCs) of the heating alternatives. The NPC formula discounts costs incurred at different time point (n) during the project life-cycle, at the discount rate $(r)$ to a common point in time, which in this study is 2020. In other words, the NPC formula allows all future numbers to be translated in terms of present value to allow logical comparison. However, the LCCs were not adjusted with inflation and with other factors as doing so for such long-term calculations could potentially introduce cumulative error. NPC calculations were applied to obtain the LCC for both home-owner and government.

$$
N P C=\sum_{n=0}^{N} \frac{C_{\mathrm{t}, \mathrm{n}}}{(1+r)^{\mathrm{n}}}
$$

To address the uncertainty in predicting these costs, sensitivity analyses were conducted to measure the effect of each input variable to the NPC. Key variables selected for sensitivity analysis were capital cost, energy cost, maintenance cost, and periodic costs for heat pump, oil boiler, oil tank and solar panels. Each variable was changed by $30 \%$, with $10 \%$ increments above and below their original values and sensitivity graphs were plotted for each heating scenario to visualize the changes in NPC. The line gradient indicates the sensitivity of the NPC to changes in each variable. A steeper slope indicates a greater effect on the NPC.

\subsubsection{Revenue from Selling in Commodity Market}

Switching from business-as-usual heating scenario in Case 1 to GCHP heating systems in Case 2 and 3 cuts the consumption of diesel. This opportunity benefit is defined as the revenue gained from selling surplus diesel in the commodity market and the avoided cost for not shipping and selling to Kuujjuaq. These costs were considered when calculating the NPCs of Cases 2 and 3. The cost of diesel was assumed to be USD $\$ 1.41 / \mathrm{gal}$ or $\$ 0.47 / 1$ based on the price of RBOB gasoline in the commodity market on January 5, 2019 [46]. The cost of shipping diesel was assumed to be the cost of diesel production before subsidy minus the cost after subsidy at $\$ 0.40 / 1$.

\subsubsection{Economic Scenarios}

In order to propose recommendation and identify areas for future improvement, the LCCAs were applied for various economic scenarios, where one to several variables were varied, while the others were held constant (Table 5). The first scenario is based on current condition and costs 
assumed above, while the second scenario show the uncertainties resulting from best $(\$ 50 / \mathrm{m})$, moderate $(\$ 175 / \mathrm{m})$ and worst $(\$ 300 / \mathrm{m})$ BHE drilling costs. The cost of drilling was assumed to be the same for drilling in both bedrock and quaternary deposits in Kuujuaq. In a more competitive market, the drilling cost tend to be more variable. However, in such a remote region, there is limited drilling service providers that the cost tends to be fixed and high. The worst-case drilling cost was assumed based on a requested quote from a drilling company in Kuujjuaq, while the bestcase drilling cost was assumed based on the typical BHE drilling cost in the south [39]. In the third and fourth economic scenarios, the effect of government incentive to the NPC can be observed, whereas the first and second economic scenarios provide an overview of the total costs of the project.

Table 5. Summary of the economic scenarios used to calculate the LCCs.

\begin{tabular}{|c|c|c|c|c|}
\hline \multirow{2}{*}{$\begin{array}{l}\text { Economic } \\
\text { Scenario }\end{array}$} & \multicolumn{2}{|c|}{ Drilling } & \multirow{2}{*}{$\begin{array}{c}\text { Energy (Diesel } \\
\text { and Electricity) } \\
\text { Subsidy }\end{array}$} & \multirow{2}{*}{$\begin{array}{c}\text { GCHP and Solar } \\
\text { Panel Costs } \\
\text { Covered by the } \\
\text { Government }\end{array}$} \\
\hline & Cost $(\$ / m)$ & $\begin{array}{c}\text { Cost Covered } \\
\text { by the } \\
\text { Government }\end{array}$ & & \\
\hline 1 & 300 & no & yes & no \\
\hline 2 & 300,175 and 50 & no & yes & no \\
\hline 3 & 300 & $50 \%$ & no & $50 \%$ \\
\hline 4 & 50 & no & no & $50 \%$ \\
\hline
\end{tabular}

\subsubsection{Assumptions}

In addition to the costs and economic scenarios stated above, the following technical assumptions were made:

1. Solar PV panels were installed south facing at an angle equal to the latitude, with no shade, such as from buildings, trees and snow.

2. Cost of solar energy storage was not considered.

3. Cost of heating distribution was not considered to limit the scope of the economic analysis.

4. Tools and parts, such as bolts and screws were considered negligible and not included.

5. Roof replacement costs incurred when solar PV panels are replaced were not considered as they need to be replaced regardless.

The following economic assumptions were made:

1. Discount rate $=6 \%[47]$.

2. Annual energy and maintenance costs escalation rates $=0 \%$.

3. Project lifetime $=50$ years.

4. Project starts in 2020 and ends in 2069.

5. No sudden fluctuation in the costs of electricity and diesel throughout the project life-cycle.

6. Depreciation rates of heating equipment not considered.

7. In the third, fourth and fifth economic scenarios, the government is assumed to bear the cost of $\mathrm{CO}_{2}$ emissions. 


\section{RESULTS}

\subsection{Shallow Geothermal Potential Maps}

The shallow geothermal potential $\bar{Q}_{B H E}$, calculated using the G.POT equation (Eq. 1) and the input parameters described in Tables 1 and 2, show heat extraction potential varying with the local geology and the ground temperature or depth of three BHE lengths in Kuujjuaq (Figure 4). 


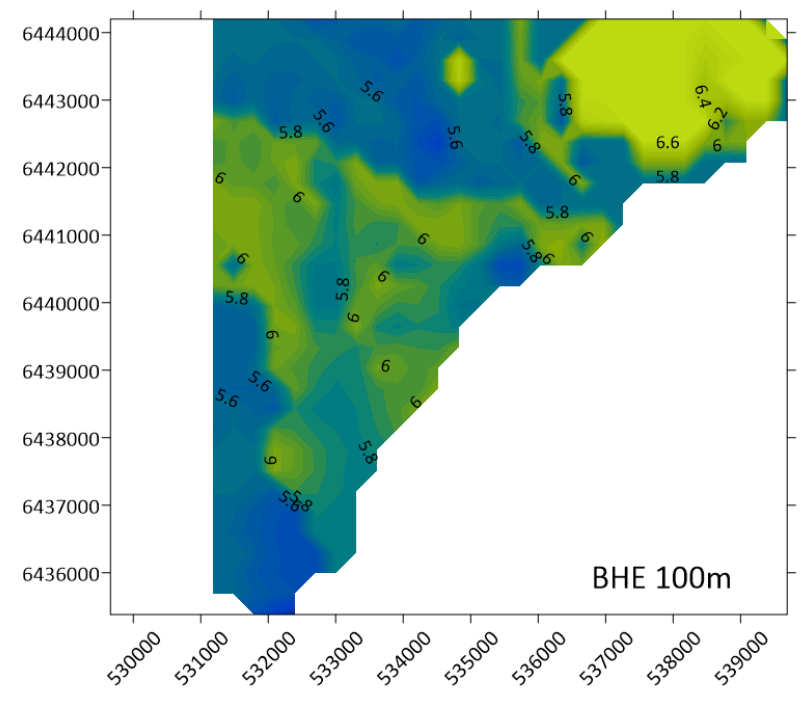

\section{Geothermal \\ Potential (MWh/y)}

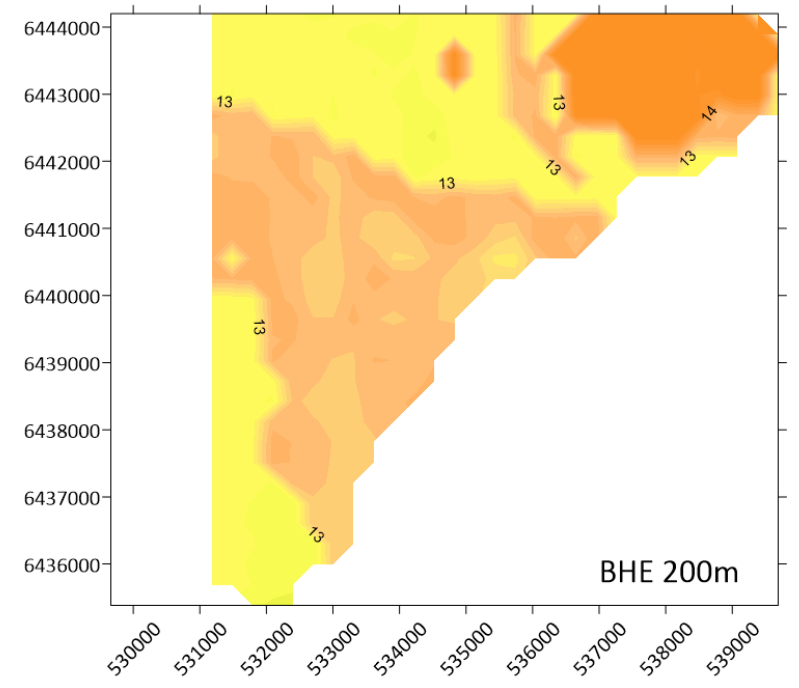

10

5

15

20

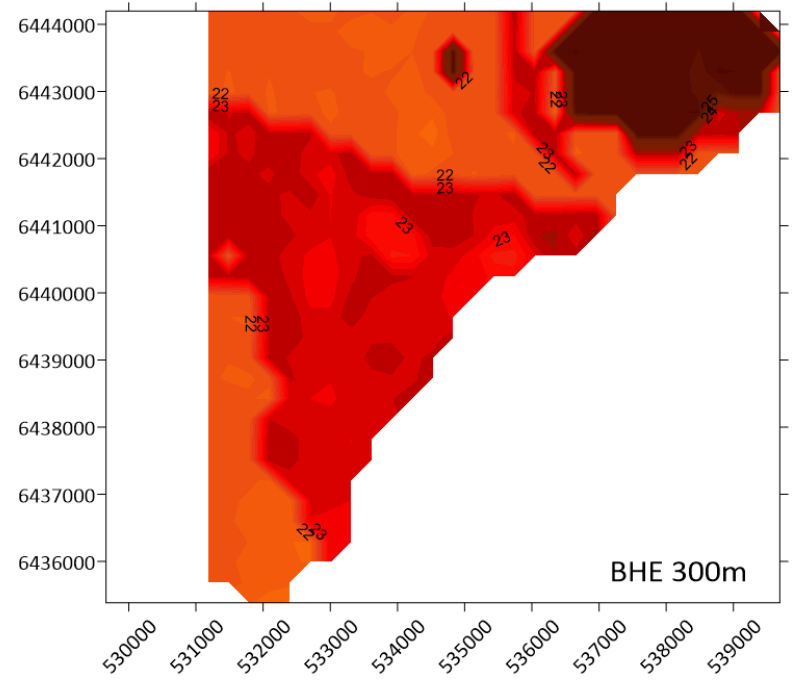

25

Figure 4. Geothermal potential maps of Kuujjuaq based on three BHE lengths of $100 \mathrm{~m}$ (top), $200 \mathrm{~m}$ (center) and $300 \mathrm{~m}$ (bottom). $\mathrm{X}$ and $\mathrm{Y}$ axes represent map coordinates (NAD83/UTM Zone $19 \mathrm{~N})$. 
The geothermal potential at $100 \mathrm{~m}$ BHE length ranged 5.2-6.6 MWh/year and averaged $5.8 \mathrm{MWh} /$ year. At $200 \mathrm{~m}$, the geothermal potential ranged 12.2-14.9 MWh/year and averaged 13.3 MWh/year. At $300 \mathrm{~m}$, the geothermal potential ranged 21.3-25.6 MWh/year and averaged 22.9 MWh/year. Thus, the geothermal potential increases supralinearly with borehole lengths due to higher temperature at greater depths and lower thermal conductivity of shallow quaternary deposits.

Geologically-accurate geothermal potential maps were successfully produced from field observations and laboratory measurements of thermal properties. In areas where the dominating bedrock lithology has lower thermal conductivity, there is generally lower geothermal potential in the area, and vice versa. For instance, in the area overlying paragneiss bedrock, which has an average thermal conductivity of $2.7 \mathrm{~W} / \mathrm{mK}$, there is lower geothermal potential. While in area that overlies the tonalites, which has an average thermal conductivity of $3.4 \mathrm{~W} / \mathrm{mK}$, there is higher geothermal potential (Table 1).

\subsection{Residential Building Heating Load}

Based on Kuujjuaq's weather data and the building parameters described previously, the annual heating load of a $252 \mathrm{~m}^{2}$ residential building in Kuujjuaq is $71,343 \mathrm{kWh}$. Figure 5 shows the daily heating load profile modelled using SIMEB.

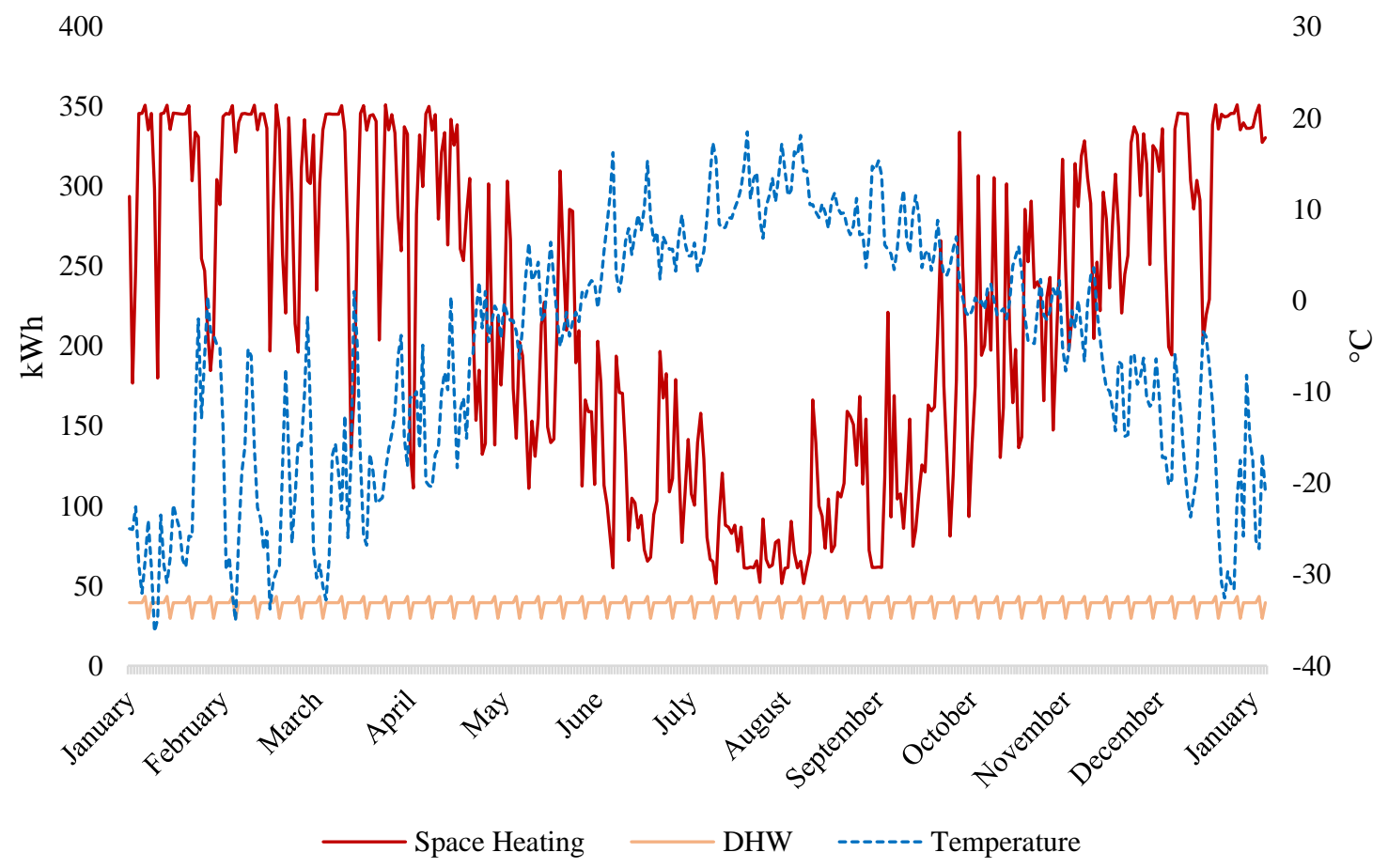

Figure 5. Average daily temperature and heating load profile of a typical residential building in Kuujjuaq. 


\subsubsection{Building Energy Consumption}

The energy consumptions for each heating equipment scenario (Fig. 3) were calculated based on the building heating load, the efficiency or COP of the heating equipment and the energy densities (Table 6). For the business-as-usual heating scenario (Case 1), this translates to an annual energy consumption of $8,174.71$ or $32.41 / \mathrm{m}^{2}$. This value is comparable to the reported annual average energy consumption of 3,100 1 diesel for a $110.9 \mathrm{~m}^{2}$ house in Kuujjuaq, which translates to an energy consumption of $28.0 \mathrm{l} / \mathrm{m}^{2}$ [12].

Table 6. Energy consumption breakdowns for different heating equipment scenarios.

\begin{tabular}{cccccc}
\hline \multirow{2}{*}{$\begin{array}{c}\text { Heating } \\
\text { Scenario }\end{array}$} & $\begin{array}{c}\text { Diesel } \\
\text { furnace }\end{array}$ & \multicolumn{4}{c}{ GCHP } \\
\cline { 2 - 6 } & Diesel (l) & $\begin{array}{c}\text { Electricity from } \\
\text { solar PV panels, } \\
E_{\mathrm{s}}(\mathrm{kWh})\end{array}$ & $\begin{array}{c}\text { Diesel for } \\
\text { GCHP (l) }\end{array}$ & $\begin{array}{c}\text { Ground } \\
\text { thermal energy, } \\
E_{\mathrm{g}}(\mathrm{kWh})\end{array}$ & $\begin{array}{c}\text { Electricity from } \\
\text { diesel power } \\
\text { plant }(\mathrm{kWh})\end{array}$ \\
\hline 1 & $8,174.7$ & 0 & 0 & 0 & 0 \\
$2 \mathrm{~A}$ & $4,253.1$ & $8,054.9$ & 0 & $2,4164.6$ & $3,452.1$ \\
$2 \mathrm{~B}$ & $4,253.1$ & $11,506.9$ & 0 & $2,4164.6$ & 0 \\
$2 \mathrm{C}$ & $4,253.1$ & 0 & 0 & $2,4164.6$ & $11,506.9$ \\
3 & $4,253.1$ & 0 & $2,764.5$ & $5,945.3$ & 0 \\
\hline
\end{tabular}

\subsubsection{BHE Drilling Lengths}

Based on the average geothermal potential in Kuujjuaq at different BHE lengths, the annual

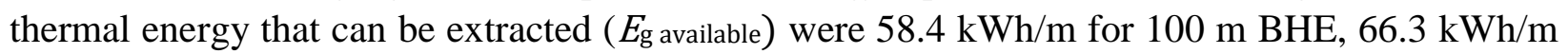
for $200 \mathrm{~m} \mathrm{BHE}$ and $76.3 \mathrm{kWh} / \mathrm{m}$ for $300 \mathrm{~m} \mathrm{BHE}$. The drilling lengths ( $\left.L_{\text {drill }}\right)$ for each type of heat pump were then calculated according to the required thermal energy from the ground $\left(E_{\mathrm{g}}\right)$. For Case 2, the $E_{\mathrm{g}}$ available from a $300 \mathrm{~m} \mathrm{BHE}$ was considered due to the high $E_{\mathrm{g}}$, while the $E_{\mathrm{g}}$ available from a $100 \mathrm{~m} \mathrm{BHE}$ was used in Case 3. Based on this, the drilling lengths required in Cases 2 and 3 were $316.5 \mathrm{~m}$ and $101.8 \mathrm{~m}$, respectively.

\subsubsection{Solar Panels Quantity}

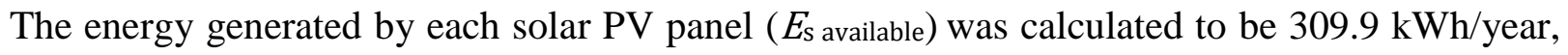
despite the perception that there would be insufficient solar energy in the north. The number of solar PV panels required $\left(N_{s}\right)$ for Case $2 \mathrm{~A}$ is 26 panels and for Case $2 \mathrm{~B}$ is 37 panels.

\subsection{Life-Cycle Cost Analysis}

The average $\mathrm{CO}_{2}$ emission considered and determined from six heating oil companies is $0.0902 \mathrm{tCO}_{2} / \mathrm{GJ}$. The cost of emission was then obtained by multiplying this value with the price of carbon and included in the NPC calculations. 


\subsubsection{Economic Scenario 1}

The results of the 50-years LCCA based on the current condition and values outlined previously are shown in Table 7. In this economic scenario, it is interesting to note that a linear trend between $\mathrm{CO}_{2}$ emissions and NPC could also be observed; the heating option emitting higher $\mathrm{CO}_{2}$ has higher 50 years total NPC (Fig. 6). Despite the high initial capital costs incurred in Cases 2A and 2B, the low annual costs combined with the high annual opportunity benefit make COMP with solar panels the most economically attractive building heating solution that also reduces $\mathrm{CO}_{2}$ emissions. Cases $2 \mathrm{~A}$ and $2 \mathrm{~B}$ are expected to have a payback period comparable to the business-as-usual scenario within 11 and 12 years, respectively, and hence can be considered fast for such major investment. 
2 Table 7. Summary of costs, cost of $\mathrm{CO}_{2}$ emissions, and NPCs of 50-years LCC for business-as-usual and alternative heating scenarios.

\begin{tabular}{|c|c|c|c|c|c|c|c|c|c|}
\hline \multirow{2}{*}{$\begin{array}{l}\text { Heating } \\
\text { Scenario }\end{array}$} & \multirow{2}{*}{$\begin{array}{l}\text { Capital } \\
\text { Cost }(\$)\end{array}$} & \multicolumn{2}{|c|}{ Annual Costs (\$) } & \multirow{2}{*}{$\begin{array}{c}\text { Periodic } \\
\text { Cost }(\$)\end{array}$} & \multirow{2}{*}{ Parts Replaced } & \multirow{2}{*}{$\begin{array}{c}\text { Annual } \\
\text { Opportunity } \\
\text { Benefit }(\$)\end{array}$} & \multirow{2}{*}{$\begin{array}{c}\mathrm{CO}_{2} \\
\text { Emissions } \\
(\mathbf{t})\end{array}$} & \multirow{2}{*}{$\begin{array}{c}\text { Annual Cost } \\
\text { of Emission } \\
(\$)\end{array}$} & \multirow{2}{*}{$\begin{array}{c}\text { Total } \\
\text { NPC (\$) }\end{array}$} \\
\hline & & Energy & Maintenance & & & & & & \\
\hline 1 & 5,063 & 16,595 & 1,059 & $\begin{array}{l}1,041 \\
4,022\end{array}$ & $\begin{array}{c}\text { Diesel tank } \\
\text { Diesel furnace }\end{array}$ & 0 & 28.5 & 554 & 276,875 \\
\hline $2 \mathrm{~A}$ & 158,324 & 8,634 & 849 & $\begin{array}{c}4,354 \\
1,041 \\
4,022 \\
39,723\end{array}$ & $\begin{array}{l}\text { Heat pump } \\
\text { Diesel tank } \\
\text { Diesel furnace } \\
\text { Solar PV panel }\end{array}$ & 9,819 & 18.0 & 350 & 203,153 \\
\hline 2B & 175,348 & 8,634 & 849 & $\begin{array}{c}4,354 \\
1,041 \\
4,022 \\
56,747\end{array}$ & $\begin{array}{l}\text { Heat pump } \\
\text { Diesel tank } \\
\text { Diesel furnace } \\
\text { Solar PV panel }\end{array}$ & 9,819 & 14.8 & 288 & 179,433 \\
\hline $2 \mathrm{C}$ & 118,601 & 18,530 & 849 & $\begin{array}{l}4,354 \\
1,041 \\
4,022\end{array}$ & $\begin{array}{l}\text { Heat pump } \\
\text { Diesel tank } \\
\text { Diesel furnace }\end{array}$ & 9,819 & 25.5 & 495 & 258,500 \\
\hline 3 & 44,484 & 14,246 & 849 & $\begin{array}{l}4,335 \\
1,041 \\
4,022 \\
\end{array}$ & $\begin{array}{c}\text { Heat pump } \\
\text { Diesel tank } \\
\text { Diesel furnace }\end{array}$ & 2,897 & 24.5 & 475 & 231,459 \\
\hline
\end{tabular}




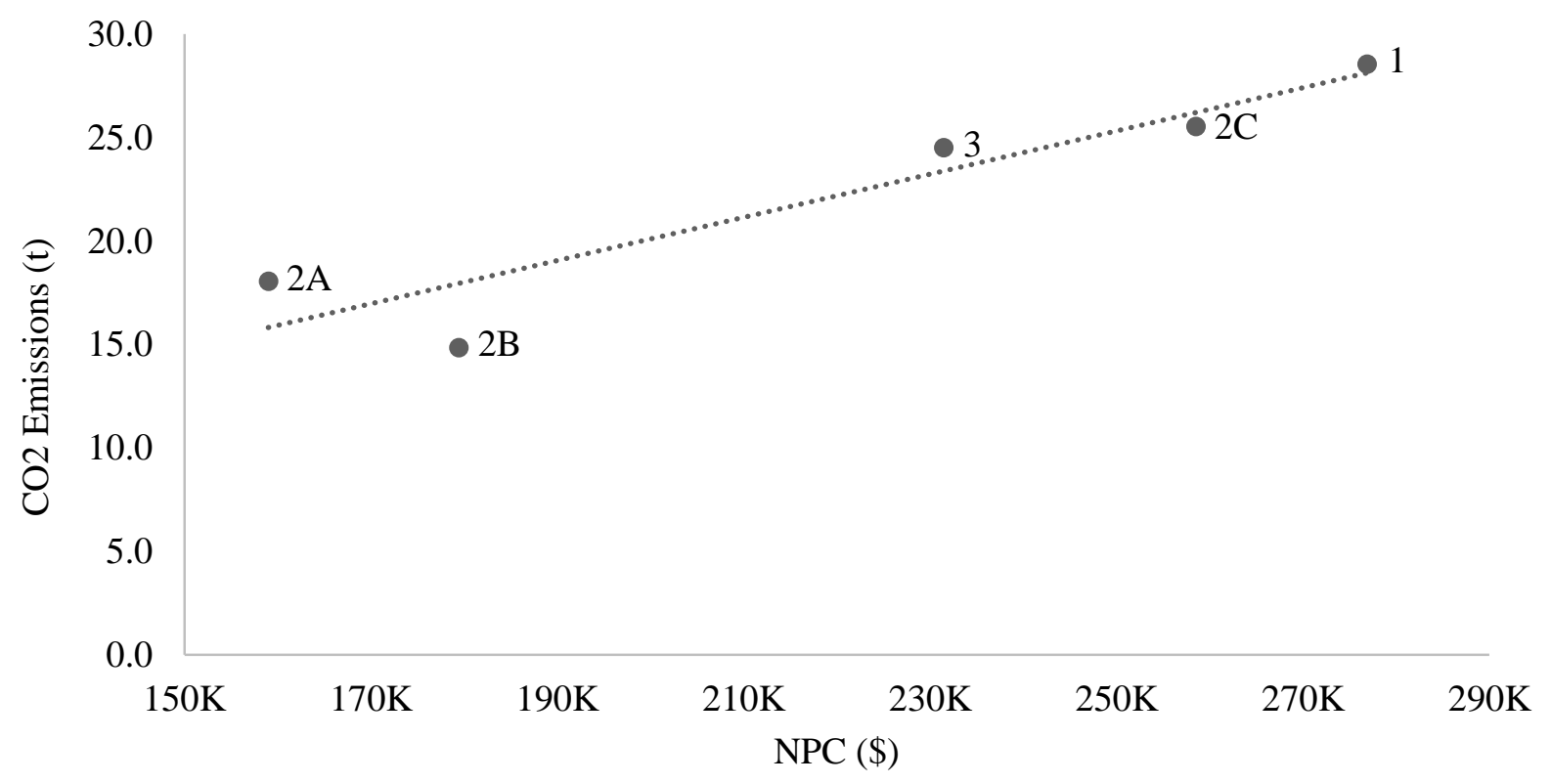

Figure 6. NPC vs. $\mathrm{CO}_{2}$ emissions of different building heating scenarios.

4 Sensitivity analyses of key inputs reveal that the most sensitive cost item for all heating equipment 5 were either the energy cost or capital cost (Fig. 7). Variations on the periodic costs and 6 maintenance cost appear to have little effect on the NPC of the LCC of the heating options. The 7 energy cost is more sensitive than the capital cost for heating options that rely heavily on diesel 8 fuel, (Cases 2C and 3). For these last options, the high energy cost, which is heavily influenced by 9 the transportation cost to the north, affects the NPC more than the capital cost, which includes the 10 cost of the heating equipment and BHE drilling in the case of GCHP heating.

\section{Case 1: Sensitivity Analysis}

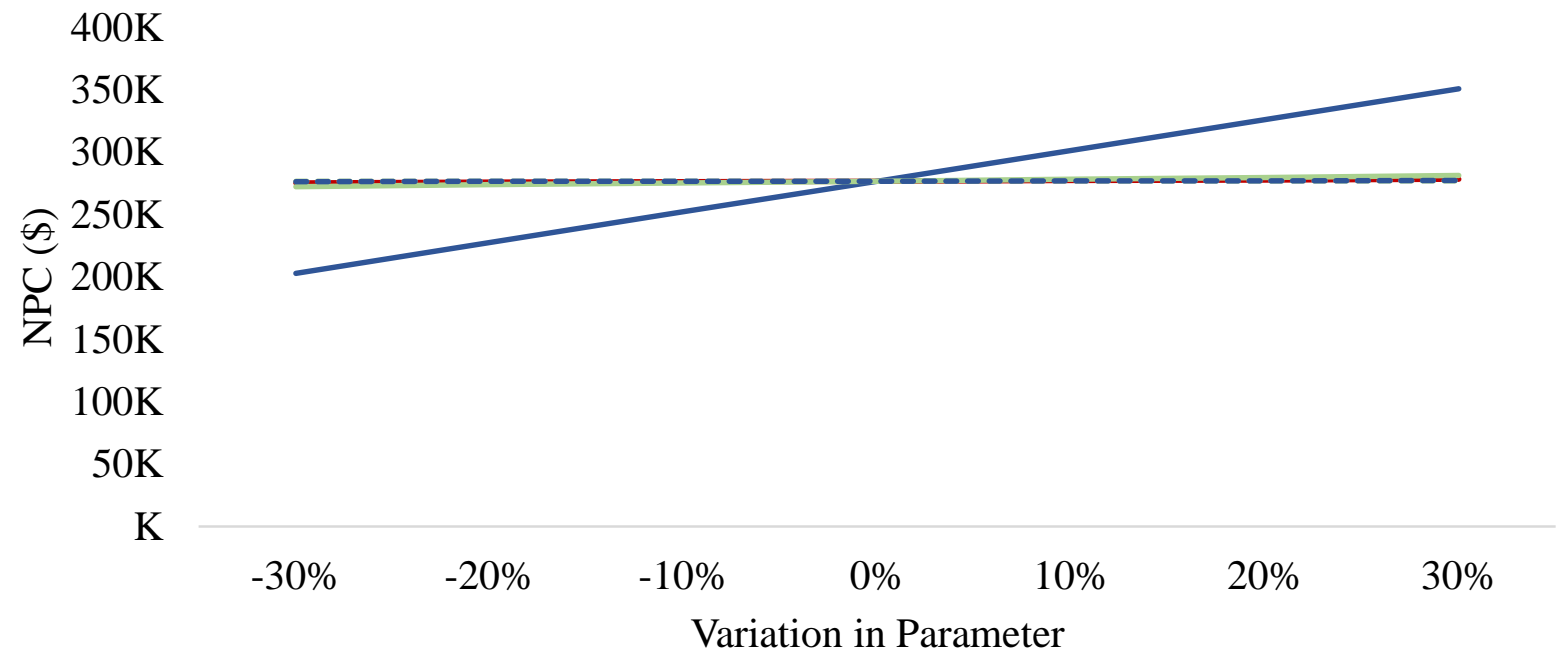


Case 2A: Sensitivity Analysis

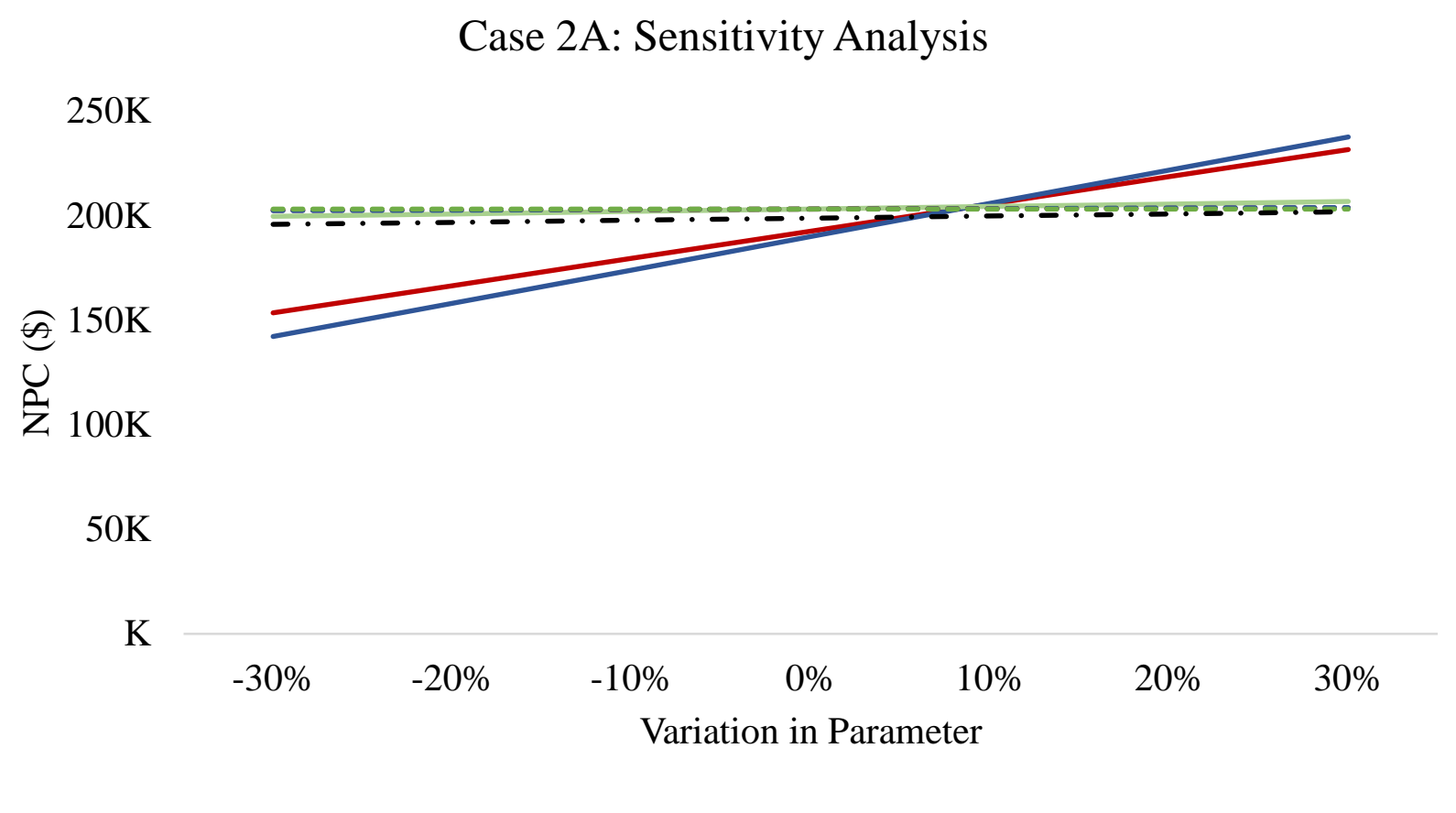

12

Case 2B: Sensitivity Analysis

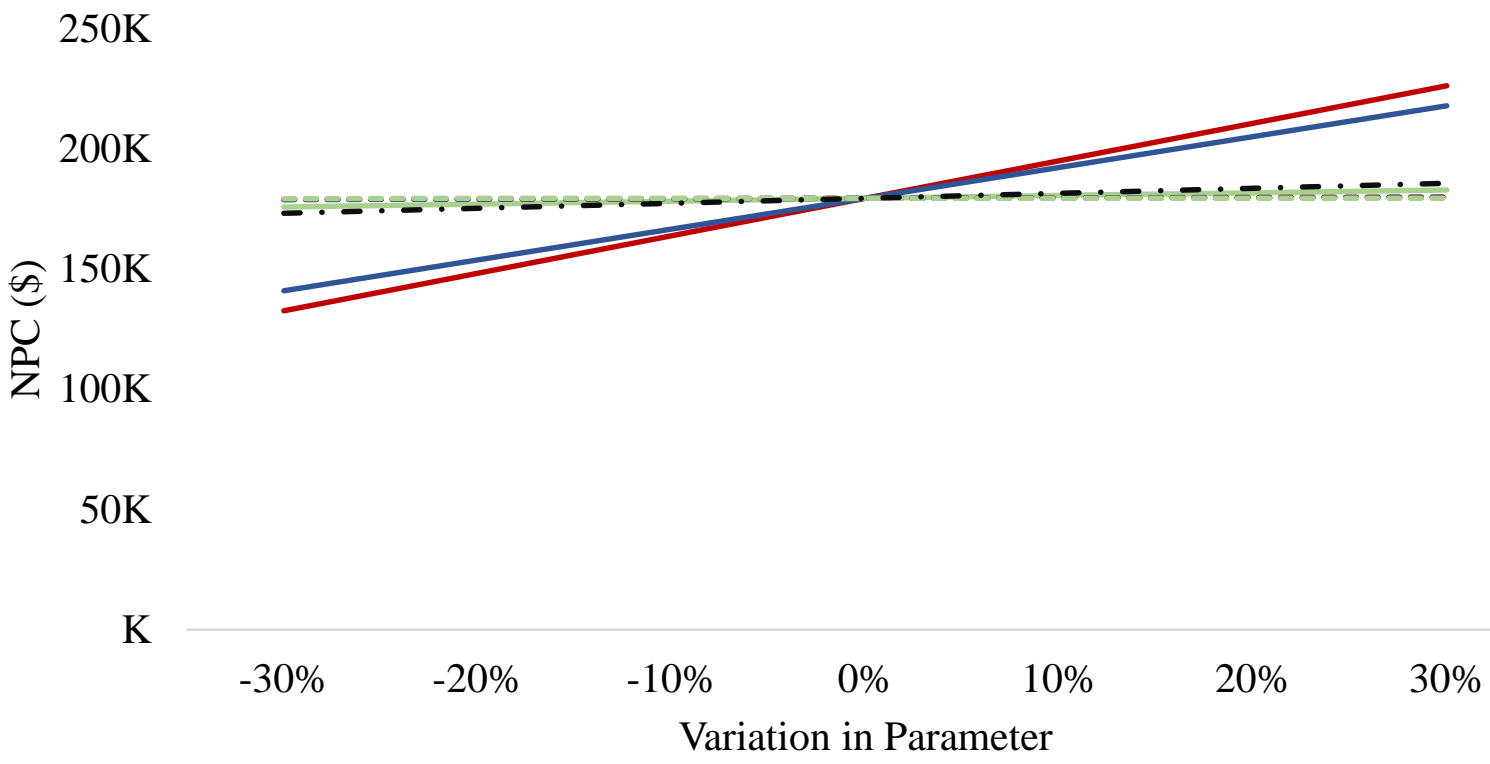




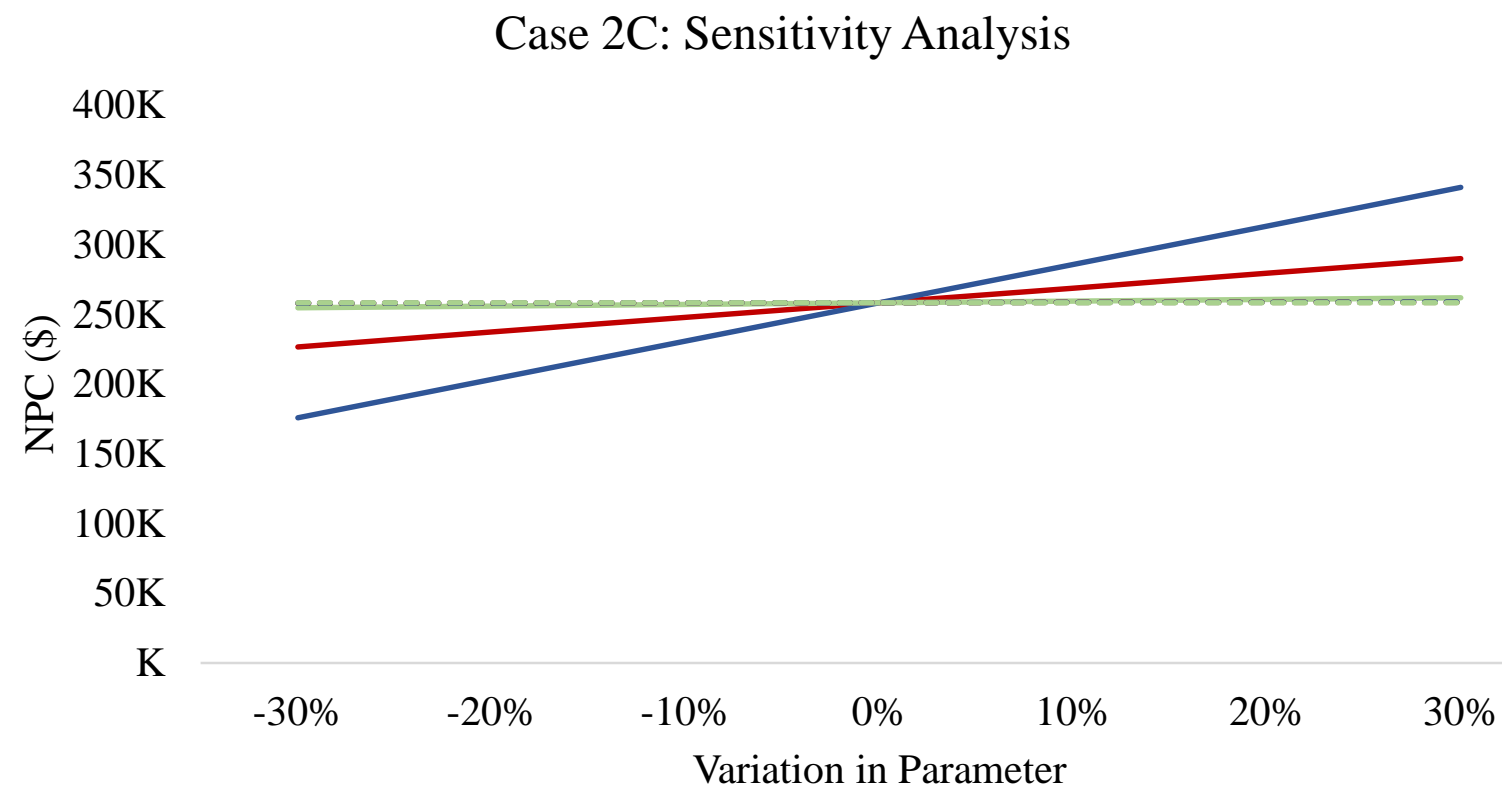

16

Case 3: Sensitivity Analysis

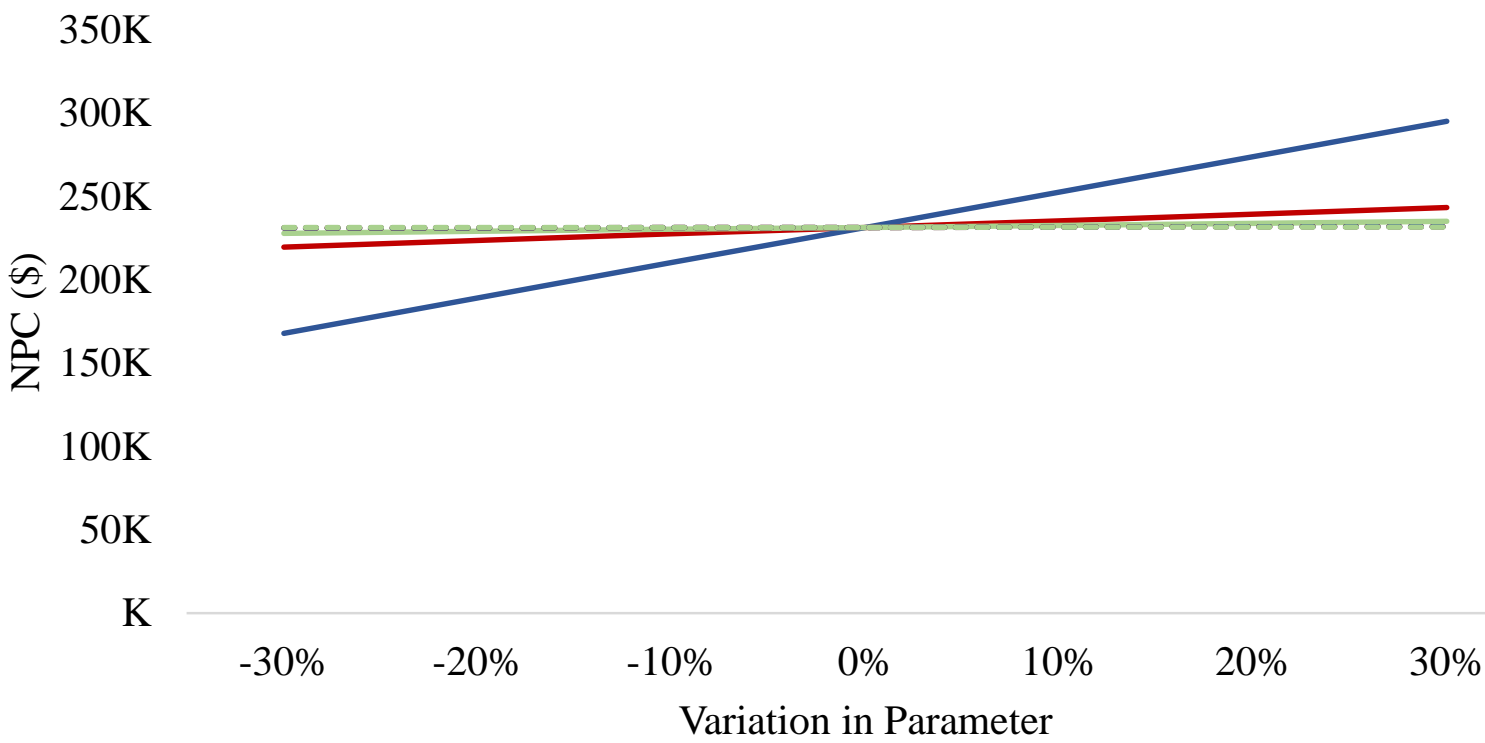

Figure 7. Sensitivity analyses of key parameters in all building heating options based on Economic Scenario 1. 


\subsubsection{Economic Scenario 2}

21 In this economic scenario, LCCs for the heating options were calculated based on three drilling costs (Fig. 8). Regardless of the drilling costs, switching to any type of GCHP seem to always be more economically attractive and will payback relatively fast within the lifetime in respect to the business-as-usual scenario. Cases $2 \mathrm{~A}$ and $2 \mathrm{~B}$ present the largest savings from the business-as-usual scenario. With the best drilling cost at $\$ 50 / \mathrm{m}$, the paybacks for these two cases are expected to significantly decrease to within 3 and 4 years, respectively. Thus, a policy to support the growth of drilling industry to lower drilling cost in the north could be beneficial, especially when considering a COMP as an alternative heating system in Kuujjuaq.
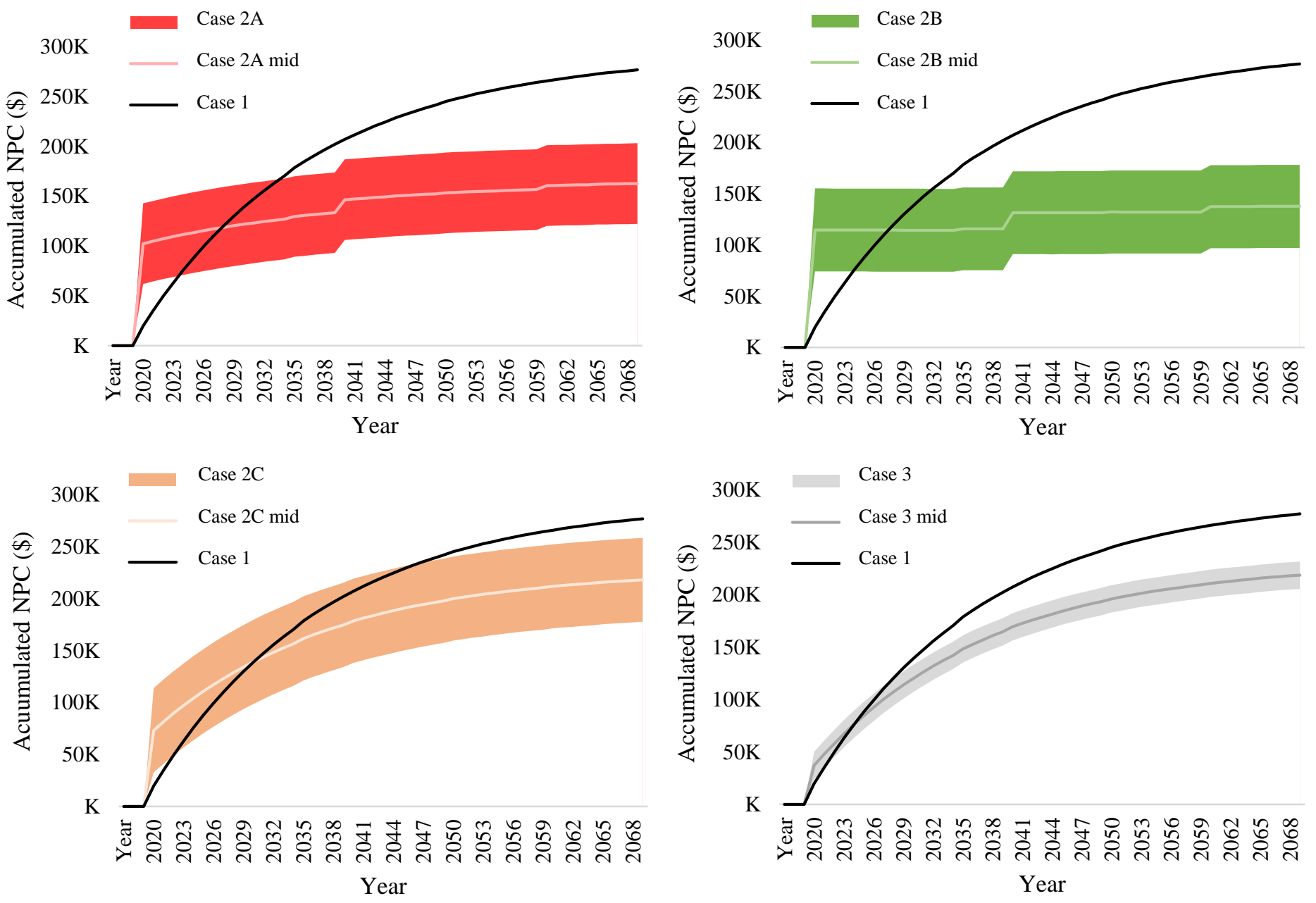

Figure 8. Range of accumulated NPCs based on worst to best BHE drilling costs compared to that of business-as-usual heating scenario (case 1).

\subsubsection{Economic Scenario 3}

30 The purpose of this analysis is to calculate a scenario in which home-owners are encouraged to 31 switch to GCHP system. Additionally, while the total NPCs remain the same for all cases as in 32 Economic Scenario 1, this scenario helps to see the breakdown of burden for home-owner and 33 government. Due to the high cost of fossil fuel in Kuujjuaq, any heating option that consumes 
34 more fossil fuel, such in Cases 1, 2C and 3, results in more uneven distribution of costs between 35 home-owner and government, with a higher proportion of the burden falling on the hands of the 36 home-owner (Table 8).

37 Table 8. Total 50 years NPCs for home-owner and government based on Economic Scenario 3.

\begin{tabular}{ccc}
\hline Heating Scenario & $\begin{array}{c}\text { Total NPC for } \\
\text { Home-Owner (\$) }\end{array}$ & $\begin{array}{c}\text { Total NPC for } \\
\text { Government (\$) }\end{array}$ \\
\hline 1 & 268,646 & 8,232 \\
2A & 149,941 & 53,211 \\
2B & 116,471 & 62,962 \\
2C & 228,039 & 30,460 \\
3 & 214,783 & 16,676 \\
\hline
\end{tabular}

\subsubsection{Economic Scenario 4}

40 Previous sensitivity analyses (Fig. 7) have shown that energy cost and capital cost are the most sensitive cost item in Cases $2 \mathrm{~A}$ and $2 \mathrm{~B}$. The purpose of this economic scenario is to analyze the effect of eliminating subsidy on diesel and electricity and lower BHE drilling cost in the north to shed light at the potential of GCHP as an optimum building heating solution in northern remote communities that can reduce both costs and $\mathrm{CO}_{2}$ emissions.

45 Although Case 2C brings profit to the government, the cost to the home-owner is high (Table 9). Business-as-usual and Case 3 are not the most viable due to the high costs incurred to the homeowner. Again, Cases 2A and 2B have the lowest total NPCs and hence, are more economically attractive compared to the business-as-usual and other heating options. Additionally, this economic scenario results in lower total NPCs for all GCHP heating (Cases 2 and 3) as compared to

50 Economic Scenario 1, which analyses NPCs based on the current conditions. This means that the 51 development of northern drilling industry and such government incentive are predicted to be 52 efficient in reducing total LCCs for any GCHP systems listed in this paper.

53 Table 9. Total 50 years NPCs for home-owner and government based on Economic Scenario 4.

\begin{tabular}{ccc}
\hline Heating Scenario & $\begin{array}{c}\text { Total NPC for } \\
\text { Home-Owner (\$) }\end{array}$ & $\begin{array}{c}\text { Total NPC for } \\
\text { Government (\$) }\end{array}$ \\
\hline 1 & 268,646 & 8,232 \\
$2 \mathrm{~A}$ & 117,550 & 4,625 \\
\hline
\end{tabular}




\begin{tabular}{ccc}
\hline 2B & 84,080 & 14,375 \\
2C & 195,648 & $-18,126$ \\
3 & 204,369 & 1,055 \\
\hline
\end{tabular}

55 Both Cases $2 \mathrm{~A}$ and $2 \mathrm{~B}$ utilizes the COMP as the main heating equipment, the only difference being 56 the proportion of electricity that comes from solar PV panels. Increasing the proportion of 57 electricity coming from solar PV panels reduces the cost of heating for the home-owner more than 58 it increases for the government (Fig. 9). Additionally, when all electricity required for the COMP 59 comes from solar PV panels, the total combined NPC for both government and home-owner, and $60 \mathrm{CO}_{2}$ emissions become lower than other proportions. Below 56\%, COMP is most economically 61 attractive for the government, as the government would have a negative total NPC, which means 62 positive cashflow or revenue through selling surplus diesel in the commodity market. It is also 63 economically attractive for home-owner. However, it is important to note that the total NPC for 64 home-owner decreases as the proportion of electricity increases. At 56\% the government breaks 65 even as the total NPC becomes zero. At 80\%, the total NPC for COMP equals the total NPC for 66 business-as-usual or diesel furnace heating scenario. Above 80\%, COMP becomes a less 67 economically attractive heating option compared to diesel furnace for the government, although it 68 is still economically attractive for the home-owner. Thus, COMP is most economically attractive 69 for both the home-owner and government alike when the proportion of electricity coming from 70 solar PV panels is below $80 \%$. 


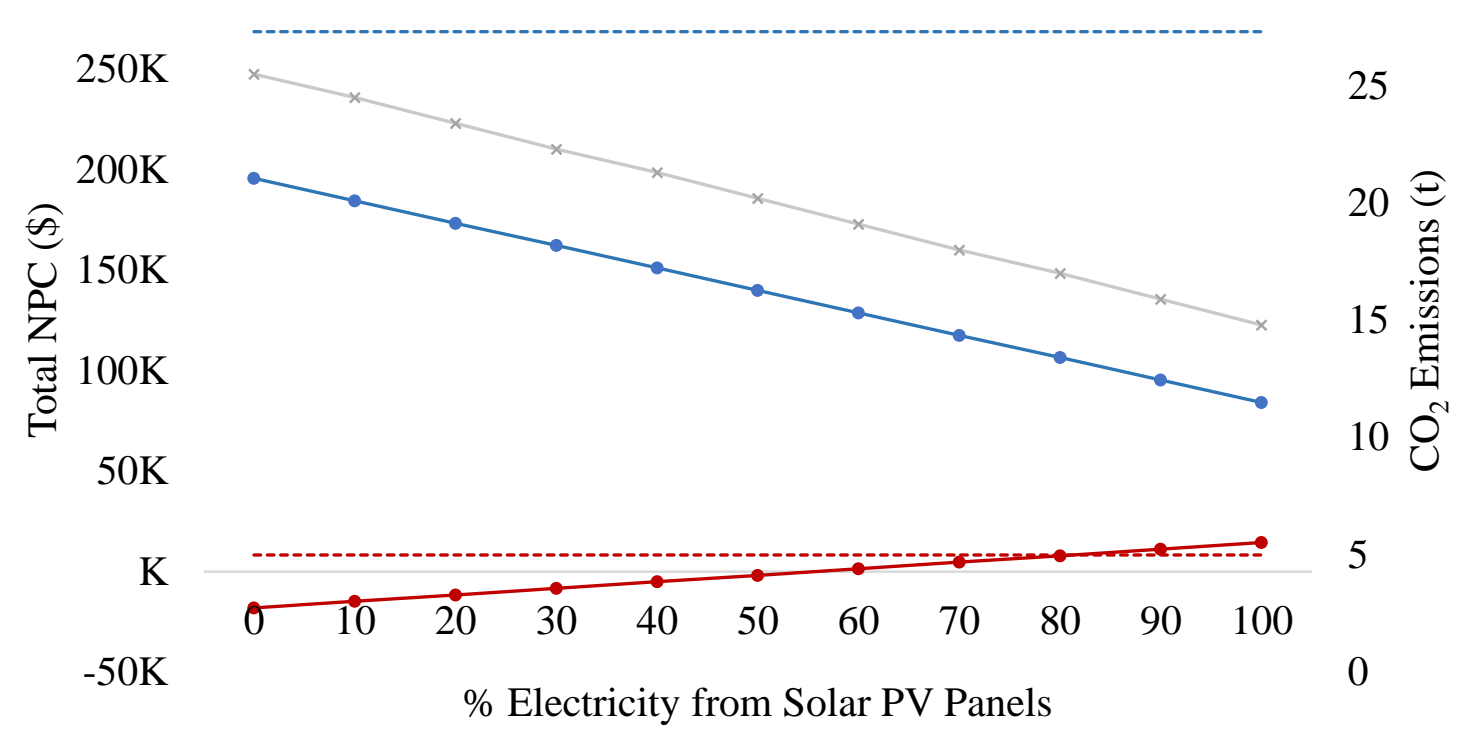
$\because$ COMP, Home-Owner $\quad \longrightarrow$ COMP, Government Diesel Furnace, Home-Owner ------- Diesel Furnace, Government CO2 Emissions

Figure 9. Optimization to determine the best proportion (\%) of electricity coming from solar panels to run a COMP for building heating in Kuujjuaq.

\section{4. DISCUSSION}

79 In this study, the COPs of the GCHP systems considered were assumed to remain constant 80 throughout the project's life-cycle, while in reality the COP would vary, albeit by little throughout

81 seasons and years. This COP assumption is conservative since it is based on the minimum water 82 temperature leaving the BHE for the 50-years period considered in the G.POT calculation. 83 Additionally, since there is currently no GCHP being operated in remote northern communities 84 with heating requirements above 8,000 HDD, the presented study is essential before moving 85 towards first demonstration or pilot projects that can provide experimental data. Thus, further study 86 on the performance of COMP and ABS operating in the area or in similar subarctic conditions 87 would be required to produce a more accurate forecast and are anticipated to potentially improve 88 the project cashflow. Additionally, the average annual solar PV potential in Kuujjuaq was used in 89 calculating the number of solar panels required in the COMP heating scenario as a simplification, 90 as a detailed solar analysis was beyond the scope of this study. Future study could hence, focus on 91 the economics of using battery storage versus sizing the solar panels according to the monthly 92 solar PV potential in Kuujjuaq. Moreover, social factors, such as acceptability and implementation 93 effort were not considered and could be a subject of future research. 
Consistent with the results from Pike and Whitney's study [12] in Alaska, heat pumps can be a viable heating technology for cold climates. The economic benefit of GCHP system, however, depends heavily on the costs of fuel and electricity in the area, and sensitivity analyses in this study demonstrated that the costs of energy form one of the most critical factors that influences the Kuujjuaq system's economic viability. In Alaska, although the costs of fuel oil and natural gas are relatively high, the cost of electricity is low [13]. For Kuujjuaq, a combination of solutions was considered and COMP with electricity from solar PV panels was found to be the most economically attractive option, as the costs of both fuel and electricity are high in this region. The energy cost of heating options relying on a greater diesel fuel proportion is less sensitive to capital cost. For this reason, the switch to renewable energy should be favored, not only for environmental reasons, but also for the economic savings obtained over the system operation. The cost of energy could thus be a tool that both governments and businesses use to simulate innovations and foster renewable energy utilization.

107 In addition to analysing the feasibility of ABS and COMP, the potential of COMP coupled with 108 solar PV panels was explored. The feasibility of solar thermal collectors for heat generation, however, was not considered mainly because heat production mostly occurs during the relatively short summer, while heating is required year long. In a previous study, the use of solar thermal collectors with underground thermal energy storage was analyzed by Giordano and Raymond [50]. In their study, the five-year technical viability of underground thermal storage for heat production for drinking water was positively confirmed through detailed transient simulations. However, they pointed out that the efficiency of thermal collectors in such cold climates can be limited due to the high amount of anti-freeze needed to run the system, and that the use of PV panels can provide better overall performance as suggested by Bourbonnais and Déry [51].

117 Moreover, this study demonstrated that drilling cost is an important key factor for the development 118 of GCHP systems in Kuujjuaq, as capital costs form the second most sensitive cost item (see 119 Section 3.3.1). While Giordano et al. [18] defined \$150/m as a threshold drilling cost for GCHP 120 to be of economic interest in the north, the detailed LCCA presented in this contribution revealed 121 that over a 50-years period, GCHPs provide relevant paybacks compared to the current diesel122 dependent situation even at the highest drilling cost considered ( $\$ 300 / \mathrm{m}$, see Fig. 8).

123 Although previous studies have proven successful utilization of GCHP technology in various cold 124 regions worldwide and the technical viability of shallow geothermal technology in the study area, 125 none have studied the detailed economic feasibility in remote subarctic region [12-18]. This study attempted to address this gap. Furthermore, the G.POT method [19] was successfully applied to estimate the shallow geothermal potential in Kuujjuaq, enabling a long-term prediction of GCHP economic performance in such climate and community. Finally, this study proposed a viable alternative to building heating in Kuujjuaq by using COMP with electricity derived from solar panels, thereby providing a solution to help this community achieve energy security and independence using a locally generated and sustainable resource. 
Presently, Nunavik's remote northern communities are heavily dependent on fossil fuel to meet their heating demands, which incurs high costs, energy dependence and net $\mathrm{CO}_{2}$ emissions. This study focused on the economic attractiveness and emissions reduction potential of ground-coupled heat pump (GCHP) as an alternative heating source. Although it is powered by either electricity or a heat source, the main advantage of GCHP lies in its ability to supply more energy than that used to operate it. Furthermore, the methods listed was applied for a case study in Kuujjuaq, the regional capital of Nunavik. However, the same workflow can be useful to quantify the shallow geothermal resources and the economical feasibility of the GCHP technology implementation for any study area. The heating options analyzed in this study were:

1. Case 1: Business-as-usual using diesel furnace

2. Case 2A: Compression GCHP with $70 \%$ of electricity derived from solar photovoltaic (PV) panels and $30 \%$ from diesel power plant

3. Case 2B: Compression GCHP with 100\% of electricity derived from solar PV panels

4. Case 2C: Compression GCHP with $100 \%$ of electricity derived from diesel power plant

5. Case 3: Absorption GCHP customized to run on diesel

The conclusions of this study can be summarized as follow:

1. Maps of the shallow geothermal potential of Kuujjuaq showed a relatively high potential for such cold region, ranging between $5.8 \mathrm{MWh} / \mathrm{year}$ and $22.9 \mathrm{MWh} / \mathrm{year}$, and that it increases more than linearly with borehole depths (Fig. 4).

2. 50-years life-cycle cost analysis based on current costs and conditions (Economic Scenario 1) revealed that all GCHP options are economically more attractive compared to the diesel furnace heating. However, compression GCHP with electricity from solar panels (Cases $2 \mathrm{~A}$ and $2 \mathrm{~B}$ ) presents the most efficient, environmentally friendly and cheapest option at a 50 -years net present cost of $\$ 179,433$, compared to diesel furnace option at $\$ 276,875$. The total predicted costs were even lower in Economic Scenario 4 when the cost of BHE drilling was reduced to $\$ 50 / \mathrm{m}$ (similar to the cost in the south) and government provides incentive by covering 50\% of GCHP and/or solar panels costs, while energy subsidies are eliminated and home-owner fully responsible for the drilling cost. In this scenario, the compression heat pump option costs as low as $\$ 84,080$ for the home-owner and $\$ 14,375$ for the government, while the diesel furnace option costs $\$ 268,646$ for home-owner and $\$ 8,232$ for the government.

3. Consistent with the results of previous studies [12,13], energy and capital costs form the most sensitive cost items for all heating options

4. The higher the proportion of electricity derived from solar panels, the lower the predicted costs for compression GCHP heating option. However, $80 \%$ was determined to be the maximum cut-off for this technology to be the more attractive heating solution compared to diesel furnace for both the government and home-owner. The optimum proportion depends on factors such as governmental budget, availability of grants and capital.

As with any development project, without the appropriate government policy to support the northern drilling industry or incentive to alleviate the cost burden from the hands of the homeowner, it could be a challenge to initiate such project, especially since there is currently a lack of 
175 local expertise to install borehole heat exchanger and geothermal heat pump systems in Nunavik.

176 Nevertheless, given a suitable human resource capacity, compression GCHP with a proportion of

177 electricity derived from solar PV panels remains the most economically attractive heating solution

178 that offsets $\mathrm{CO}_{2}$ emissions based on the conditions listed in this study.

180 DECLARATION OF INTEREST

181 None

\section{ACKNOWLEDGEMENT}

184 The authors would like to thank the Institut Nordique du Québec (INQ) for financially supporting 185 this project through the Northern Geothermal Potential Research Chair awarded to Dr. Jasmin 186 Raymond. The Centre d'études nordiques (CEN) and the Observatoire Hommes Milieux 187 International (OHMI) Nunavik are further acknowledged for help with field campaigns allowing 188 to evaluate ground thermal properties prior to this work.

\section{LIST OF SYMBOLS}

191 Symbols

$192 \quad C_{\mathrm{a}}$

$193 E_{\mathrm{t}}$

$194 L$

$195 r_{\mathrm{b}}$

$196 R_{\mathrm{b}}$

$197 C_{\mathrm{c}}$

$198 u_{\mathrm{s}}^{\prime}$

$199 r$

$200 E_{\text {s }}$

$201 \quad E_{\mathrm{S}}$ available

$202 \rho c$

$203 t_{\mathrm{c}}$

$204 N_{\mathrm{s}}$

$205 t^{\prime}{ }_{\mathrm{c}}$

$206 C_{\mathrm{p}}$

$207 \bar{Q}_{\mathrm{BHE}}$

$208 t_{\mathrm{s}}$

$209 u_{c}^{\prime}$

$210 \lambda$

$211 \quad E_{\text {g available }}$
Annual cost (\$)

Annual energy output (kWh/year)

Borehole length (m)

Borehole radius $(\mathrm{m})$

Borehole thermal resistance $(\mathrm{Mk} / \mathrm{W})$

Capital cost (\$)

Cycle time parameter

Discount rate $(\%)$

Electricity demand to be met by solar PV panels (kWh/year)

Electricity generated by each solar PV panels (kWh/year)

Heat capacity $\left(\mathrm{MJ} / \mathrm{m}^{3} \mathrm{~K}\right)$

Length o the heating season (days)

Number of solar PV panels

Operating time ratio

Periodic cost (\$)

Shallow geothermal potential (MWh/year)

Simulated lifetime (years)

Simulation time parameter

Thermal conductivity (W/Mk)

Thermal energy available per meter drilled (MWh/year-m) 


$\begin{array}{lll}212 & T_{\text {lim }} & \text { Threshold fluid temperature }\left({ }^{\circ} \mathrm{C}\right) \\ 213 & \mathrm{n} & \text { Time point }(\text { Year } 0,1,2, \ldots) \\ 214 & L_{\text {drill }} & \text { Total BHE drilling length } \\ 215 & C_{\mathrm{t}} & \text { Total cost }(\$) \\ 216 & E_{\mathrm{g}} & \text { Total ground load }(\mathrm{kWh} / \text { year }) \\ 217 & T_{0} & \text { Undisturbed ground temperature }\left({ }^{\circ} \mathrm{C}\right) \\ 218 & & \\ 219 & \text { Acronyms } & \\ 220 & \text { ABS } & \text { Absorption ground-source heat pump } \\ 221 & \text { BHE } & \text { Borehole heat exchanger } \\ 222 & \text { CAD } & \text { Canadian dollars } \\ 223 & \text { CO } 2 & \text { Carbon dioxide } \\ 224 & \text { COMP } & \text { Compression heat pump } \\ 225 & \text { COP } & \text { Coefficient of performance } \\ 226 & \text { DHW } & \text { Domestic hot water } \\ 227 & \text { EWT } & \text { Entering water temperature } \\ 228 & \text { GHG } & \text { Greenhouse gas } \\ 229 & \text { GIS } & \text { Geographic Information System } \\ 230 & \text { GGHP } & \text { Ground-coupled heat pump } \\ 231 & \text { GUE } & \text { Gas utilization efficiency } \\ 232 & \text { HDD } 18 & \text { Heating degree days below } 18^{\circ} \mathrm{C} \\ 233 & \text { LCC } & \text { Life-cycle cost } \\ 234 & \text { LCCA } & \text { Life-cycle cost analysis } \\ 235 & \text { LCOE } & \text { Levelized cost of electricity } \\ 236 & \text { NPC } & \text { Net Present Cost } \\ 237 & \text { EERE } & \text { Office of Energy Efficiency and Renewable Energy } \\ 238 & \text { PV } & \text { Photovoltaic } \\ 239 & \text { RBOB } & \text { Reformulated gasoline blendstock for oxygen blending } \\ 240 & \text { RSI } & \text { R-value Systeme International } \\ 241 & \text { SH } & \text { Space heating } \\ 242 & \text { SHGC } & \text { Solar Heat Gain Coefficient } \\ 243 & \text { USD } & \text { United States dollars } \\ 244 & & \end{array}$

\section{REFERENCES}

246 [1] Makivik Corporation (2018). Rise in the Cost of Gasoline. Retrieved from 247 https://www.makivik.org/rise-in-the-cost-of-gasoline/

248 [2] Weis, T. M., \& Ilinca, A. (2010). Assessing the potential for a wind power incentive for remote 249 villages in Canada. Energy Policy, 38(10), 5504-5511. doi:10.1016/j.enpol.2010.04.039

250 [3] SHQ (2018). Housing Construction in Nunavik: Guide to good practices (Rep.). Retrieved 251 September 27, 2018, from Société d'habitation du Québec website: 
http://www.habitation.gouv.qc.ca/fileadmin/internet/documents/English/HousingConstructionIn

253 Nunavik.pdf

[4] Statistics Canada (2016). Inuit: Fact Sheet for Nunavik. Retrieved from https://www150.statcan.gc.ca/n1/pub/89-656-x/89-656-x2016016-eng.htm

[5] Hydro-Québec (2011). Réseaux autonomes, portrait d'ensemble et perspectives d'avenir. Demande R-3776. Retrieved from http://publicsde.regie-energie.qc.ca/projets/40/DocPrj/R-37762011-B-0058-DEMANDE-PIECE-2011_08_01.pdf

[6] Karanasios, K., \& Parker, P. (2016). Recent Developments in Renewable Energy in Remote Aboriginal Communities, Québec, Canada. Papers in Canadian Economic Development,16. http://dx.doi.org/10.15353/pced.v16i0

[7] Yan, C., Rousse, D., \& Glaus, M. (2019). Multi-criteria decision analysis ranking alternative heating systems for remote communities in Nunavik. Journal of Cleaner Production, 208, 14881497. doi:10.1016/j.jclepro.2018.10.104

[8] Comeau et al. (2017). Geothermal potential of Northern Québec: A regional assessment. GRC Transactions 41: 1076-1094

[9] Giordano, N., Kanzari, I., Miranda, M. M., Dezayes, C., \& Raymond, J. (2017). Shallow 268 Geothermal Resource Assessments for the Northern Community of Kuujjuaq, Québec, Canada. 269 In IGCP636 Annual Meeting 2017. Santiago de Chile.

270 [10] Miranda M.M., Dezayes C., Giordano N., Kanzari I., Raymond J., Carvalho J. (2018). Fracture Network Characterization as input for Geothermal Energy Research: Preliminary data from Kuujjuaq, Northern Québec, Canada. Proceedings of 43rd Workshop on Geothermal Reservoir Engineering. Standford, United States, SGP-TR-213, 12 pp.

278 [12] Pike, C., \& Whitney, E. (2017). Heat pump technology: An Alaska case study. Journal of 279 Renewable and Sustainable Energy, 9(6), 61706. doi:10.1063/1.4986584

280 [13] Garber-Slaght, R., Craven, C., Peterson, R., \& Daanen, R. P. (2017). Ground-coupled Heat 281 Pump Demonstration in Fairbanks, Alaska (Rep.). Retrieved December 27, 2018, from Cold 282 Climate Housing Research Centre (CCHRC) website: 283 http://www.cchrc.org/sites/default/files/docs/CCHRC GCHP final report.pdf

284 [14] Healy, P. F., \& Ugursal, V. I. (1997). Performance and economic feasibility of ground-coupled 285 heat pumps in cold climate. International Journal of Energy Research, 21(10), 857-870. doi:10.1002/(SICI)1099-114X(199708)21:10<857::AID-ER279>3.0.CO;2-1 
[15] Fontaine, P-O., Marcotte, D., Pasquier, P., Thibodeau, D., 2011. Modeling of horizontal geoexchange systems for building heating and permafrost stabilization. Geothermics, 40(3): 211220

290 [16] Belzile P, Comeau F-A, Raymond J, Lamarche L, Carreau M. 2017. Arctic climate horizontal ground-coupled heat pump. Geothermal Resources Council Transactions 41: 1958-1978. [17] Giordano N. and Raymond J. 2019. Alternative and sustainable heat production for drinking water needs in Nunavik (Canada): borehole thermal energy storage to reduce fossil fuel dependency in off-grid communities. Applied Energy.

[18] Giordano N., Riggi L., Della Valentina S., Casasso A., Mandrone G., Raymond J. 2019. Efficiency evaluation of borehole heat exchangers in Nunavik, Québec, Canada. Proceedings of 25th IIR International Congress of Refrigeration, Montréal, Canada, doi: 10.18462/iir.icr.2019.547.

[19] Casasso, A., \& Sethi, R. (2016). G.POT: A quantitative method for the assessment and mapping of the shallow geothermal potential. Energy, 106, 765-773. doi:10.1016/j.energy.2016.03.091

[20] Kanzari, I., Giordano, N., Miranda, M. M., Raymond, J., Dezayes, C. (2018). Conception préliminaire et évaluation du potentiel d'installations géothermiques superficielles au Nunavik. In McGill Northern Research Day 2018. Montreal, Québec.

[21] Della Valentina, S., Chicco, J., Giordano, N., Casasso, A., Sethi, R., Mandrone, G., \& Raymond, J. (2018). Mapping the Geothermal Potential of a Borehole Heat Exchanger in Kuujjuaq, Québec, Canada. In Resources for Future Generations 2018. Retrieved August 13, 2018, from http://www.rfg2018.org/

[22] Ministère de l'Énergie et des Ressources Naturelles. (2003). Système d'information géominière $\mathrm{du}$ Québec. Retrieved August 7, 2018, from $311 \mathrm{http} / / /$ sigeom.mines.gouv.qc.ca/signet/classes/I1108_afchCarteIntr

312 [23] QGIS Development Team (2016). QGIS Geographic Information System. Open Source 313 Geospatial Foundation Project. http://qgis.osgeo.org

314 [24] Golden Software LLC (2009). Surfer® 9 [Windows]. Golden, Colorado

315 [25] SIMEB (n.d.). Conversion de fichiers météo. Retrieved September 26, 2018, from 316 https://www.simeb.ca:8443/index_fr.jsp

317 [26] EnergyPlus (n.d.). Weather Data. Retrieved September 26, 2018, from 318 https://energyplus.net/weather

319 [27] Wilson, E. (2013). Commercial and Residential Hourly Load Profiles for all TMY3 Locations 320 in the United States - OpenEI Datasets. Retrieved September 25, 2018, from 
321 https:/openei.org/datasets/dataset/commercial-and-residential-hourly-load-profiles-for-all-tmy3-

322 locations-in-the-united-states

323 [28] Wilson, E., Metzger, C. E., Horowitz, S., \& Hendron, R. (2014). 2014 Building America 324 House Simulation Protocols (Tech. No. 5500-60988). Golden, Colorado: National Renewable 325 Energy Laboratory. Retrieved from https://www.nrel.gov/docs/fy14osti/60988.pdf

326 [29] Kummert, M., Bernier, M., Costa, A., \& Paris, J. (2007). A comparison between geothermal 327 absorption and compression heat pumps for space conditioning. International Journal of 328 Environmental Studies, 64(4), 467-487. doi:10.1080/00207230701382115

329 [30] ClimateMaster. (2016). Tranquility Compact Belt Drive (TC) Series Submittal Data Models 330 TCH072-120 TCV-072-300 60Hz-HFC410A. Retrieved from 331 https://www.climatemaster.com/download/18.274be999165850ccd5b5c48/1535543869128/1c517 332 -climatemaster-commercial-tranquility-compact-belt-drive-tchv-series-water-source-heat-pump333 submittal-set.pdf

334 [31] Robur. (2010). Submittal Data GAHP Line W LB Series. Retrieved from

337 [32] Belzile, P., Comeau, F. A., Raymond, J., \& Lamarche, L. (2017, June 14). Revue 338 technologique: Efficacité énergétique et énergies renouvelables au nord du Québec (Rep.). 339 Retrieved http://espace.inrs.ca/id/eprint/5308

340 [33] Natural Resources Canada (2013, November 16). ARCHIVED - Step 1: Calculate Your 341 Energy Costs and Consumption. Retrieved from 342 https://www.nrcan.gc.ca/energy/publications/efficiency/buildings/6561

343 [34] Natural Resources Canada (2017, March 20). Photovoltaic and solar resource maps. Retrieved 344 from https://www.nrcan.gc.ca/18366

345 [35] RBC Bank (2018). CAD-USD Currency Converter. Retrieved from 346 https://www.rbcbank.com/cgi-bin/tools/cadusd-foreign-exchange-calculator/start.cgi

347 [36] Hydro-Québec (2018). 2018 Electricity Rates. Retrieved from 348 http://www.hydroQuébec.com/data/documents-donnees/pdf/electricity-rates.pdf

349 [37] The Home Depot (2018). Vertical 275 Gal. Oil Tank. Retrieved from 350 https:/www.homedepot.com/p/Vertical-275-Gal-Oil-Tank-275VOT/300636041

351 [38] The Home Depot (2018). Boilers. Retrieved from https://www.homedepot.com/b/Heating352 Venting-Cooling-Heaters-Boilers/Heating-Oil/N-5yc1vZc4m2Z1z0z70u

353 [39] Avataa-Rouillier (2018, April 30). Personal communication. 
354 [40] Energyhub.org (2018). Cost of Solar Power in Canada 2018. Retrieved from 355 https://solarpanelpower.ca/cost-solar-panels-canada/\#watt

356 [41] Indeed (2018). Régie Régionale De La Santé Et Des Services Sociaux Nunavik. Retrieved 357 fromhttps://ca.indeed.com/cmp/R\%C3\%A9gie-R\%C3\%A9gionale-De-La-Sant\%C3\%A9-Et-

358 Des-Services-Sociaux-

359 Nunavik/salaries?job_category=install\&location=CA\%2FQC\%2FKuujjuaq

360 [42] Bloomquist, R. G. (2001). The Economics of Geothermal Heat Pump Systems for 361 Commercial and Institutional Buildings. In International Summer School on Direct Application of 362 Geothermal Energy

363 [43] NEAS (2018). Nunavik Sealift Rates. Retrieved from https://neas.ca/rates/

364 [44] Oil-Climate Index (2015). Viewing Total Emissions. Retrieved from 365 https://oci.carnegieendowment.org/\#total-

366 emissions?ratioSelect=perMJ\&regionSelect=North\%20America\&oiltypeSelect=Light

367 [45] Tasker, J. P. (2016, October 03). Retrieved from https://www.cbc.ca/news/politics/provinces368 with-carbon-pricing-1.3789174

369 [46] Business Insider. (2019). RBOB Gasoline. Retrieved from $370 \mathrm{https} / / /$ markets.businessinsider.com/commodities/rbob-gasoline

371 [47] Freyman, T., \& Tran, T. (2018, January). Renewable Energy Discount Rate Survey Results $3722017 \quad$ (Rep.). Retrieved https://www.grantthornton.ie/globalassets/1.-member373 firms/ireland/insights/publications/grant-thornton---renewable-energy-discount-rate-survey374 2017.pdf

375 [48] OpenEI. (2017). Building Characteristics for Residential Hourly Load Data (Rep.). Retrieved 376 September 26, 2018, from National Renewable Energy Laboratory website: 377 https://openei.org/doe-opendata/dataset/eadfbd10-67a2-4f64-a394-

378 3176c7b686c1/resource/cd6704ba-3f53-4632-8d08-

379 c9597842fde3/download/buildingcharacteristicsforresidentialhourlyloaddata.pdf

380 [49] ASHRAE. (2013). ASHRAE Standard: Ventilation for Acceptable Indoor Air Quality (Rep.). 381 Retrieved September 27, 2018, from American Society of Heating, Refrigerating and Air382 Conditioning Engineers, Inc website: http://arco-hvac.ir/wp-content/uploads/2016/04/ASHRAE383 62_1-2010.pdf

384 [50] Giordano, N., \& Raymond, J. (2019). Alternative and sustainable heat production for 385 drinking water needs in a subarctic climate (Nunavik, Canada): Borehole thermal energy storage 386 to reduce fossil fuel dependency in off-grid communities. Applied Energy, 252, 113463. 387 doi:10.1016/j.apenergy.2019.113463

388 [51] Bourbonnais, M., Déry, P. (2018) Le chauffe-eau solaire photovoltaïque (PV). Une option 389 prometteuse pour le développement du solaire au Québec? Électricité Québec, 65, 8-20. 